\title{
Kablo Sektöründe Tedarikçi Seçimi İçin Bütünleşik DEMATEL-AAS-VIKOR Yönteminin KullanıIması
}

\author{
Using Integrated DEMATEL-ANP-VIKOR Method for Supplier Selection in Cable Sector
}

\author{
Illker Murat AR ${ }^{1}$, Haluk GÖKŞEN², Mehmet Arif TUNCER ${ }^{3}$
}

\section{ÖZET}

Bu çalışmanın temel amacı, kablo sektöründe polietilen tedarikçisi seçim kriterlerini belirlemek, kriterler arası ilişkileri ortaya koymak ve kriterlerin önem düzeylerini saptayarak tedarikçi seçimi uygulamasını gerçekleştirmektir. Çalışmanın bu amaçlarına ulaşabilmek için sırasıyla DEMATEL, Analitik Ağ Süreci ve VIKOR yöntemleri kullanılmıştır. Analiz sonuçları, "ürün fiyatının uygunluğu"nun tedarikçi seçiminde en önemli kriter olduğunu ortaya koymuştur. Ayrıca en uygun tedarikçinin yer aldığı uzlaşık çözüm kümesi, iki firmadan oluşmuştur.

Anahtar kelimeler: Tedarikçi Seçimi, DEMATEL, Analitik Ağ Süreci, VIKOR.

\section{GiRiş}

Günümüzde, gelişen teknoloji ve küreselleşmenin beraberinde getirdiği zorlu rekabet koşulları altında, işletmelerin faaliyetlerini sürdürebilmesi için tedarikçi seçimi ve ilişkilerine önem göstermesi gerekmektedir. Bu işletmelerin başarılı bir şekilde faaliyet göstermelerinin önemli ölçüde tedarik fonksiyonunun uygun işleyişine bağlı olduğu belirtilmektedir (Dağdeviren vd., 2006).

Tedarikçi seçiminin amacı, işletmelerin istek ve ihtiyaçları doğrultusunda en uygun tedarikçilerin belirlenmesidir. Bir işletmede doğru tedarikçilerle çalışmak; satınalma maliyetlerini azaltacak, müşteri memnuniyetini arttıracak ve rekabet yeteneğini geliştirecektir. Ghodsypur ve O'Brien (1998)'e göre birçok işletmede satın alınan ve tedarik edilen hammadde ve yarı mamul maliyeti, toplam maliyetin önemli bir bölümünü oluşturmaktadır. Bundan dolayı Liu ve Hai

\begin{abstract}
The main purpose of this study is to determine the polyethylene supplier selection criteria in the cable industry, to identify the relationships between criteria and to perform the application of supplier selection by determining the level of importance. In order to reach this objective of the study, DEMATEL, Analytic Network Process and VIKOR methods were used respectively. The results of the analysis indicated that the "suitability of the product price" is defined as the most important criteria. Also, compromising solution set where the most suitable supplier is composed of two companies.
\end{abstract}

Keywords: Supplier Selection, DEMATEL, Analytical Network Process, VIKOR.

(2005), günümüz yüksek rekabet ortamında etkili bir tedarikçi seçimi kararının, bir organizasyonun başarıIı olmasında çok önemli olduğunu ifade etmektedir. Öz ve Baykoç (2004) ise tedarikçilerin gösterecekleri performans düzeyinin, ana firmanın müşterilerine göstereceği performansta önemli bir etkiye sahip olduğunu ifade etmiştir.

Bu çalışma, bilginin yayılımını sağlayan verilerin iletiminde önemli bir rol üstlenen kablo sektöründe gerçekleştirilmiştir. Kablo sektörü, Türkiye ekonomisi açısından giderek önem kazanmakla birlikte kaliteli ve hızlı veri iletimi noktasında da büyük bir öneme sahiptir. Türkiye'de 2004-2012 yılları arasında gerçekleşen kablo ihracatındaki artış (Şekil 1), sektörün önemini ortaya koymaktadır. Üretim kapasitesi açısından dünyada onuncu sırada yer alan sektörün ürünleri, Avrupa, Ortadoğu ve Türki Cumhuriyetlere ihraç edilmektedir (URL 1).

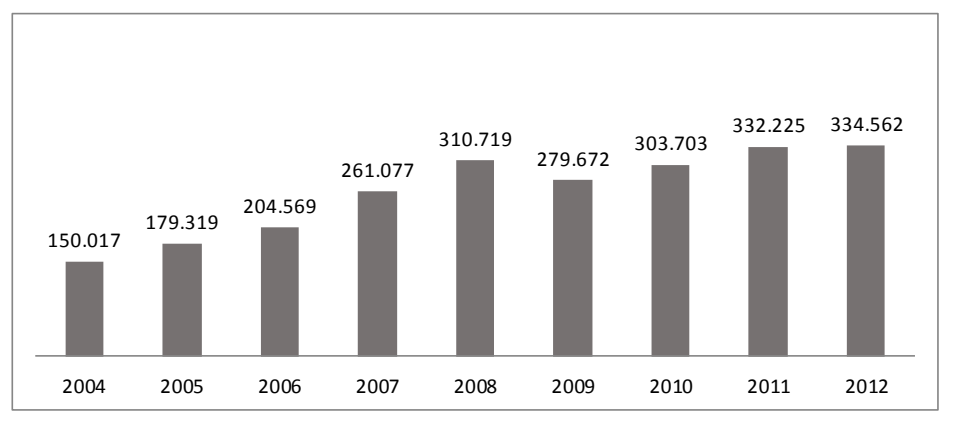

Şekil 1: 2004-2012 yılları arasındaki toplam kablo ihracatı (ton) (URL 2)

' Doç.Dr., Karadeniz Teknik Üniversitesi, iiBF, İşletme Bölümü, Trabzon, ilkerar@ktu.edu.tr 
Çalışmanın amacı, kablo sektöründe polietilen tedarikçisi seçim kriterlerinin belirlenmesi, kriterler arası ilişkilerin ve önem düzeylerinin saptanarak tedarikçi seçimi faaliyetinin gerçekleştirilmesidir. Bu nedenle çalışma kapsamında kablo sektöründe faaliyet gösteren on işletmenin polietilen tedarikçi seçim süreci analiz edilmiş, işletmelerin satınalma ve/veya teknik personellerinden oluşan on kişilik uzman grup ile tedarikçi seçim kriterleri belirlenmiştir. Kriterler arası ilişkinin saptanması sürecinde DEMATEL, kriter ağırlıklarının belirlenmesi aşamasında AAS ve tedarikçi seçiminin gerçekleştirilmesinde VIKOR yöntemi kullanılmıştır.

Çalışmanın bundan sonraki bölümlerinde ilk olarak tedarikçi seçim kriterleri ve tedarikçi seçiminde ÇKKV yöntemlerini içerisinde barındıran literatür taramasına yer verilmiştir. Üçüncü bölümde DEMATEL, AAS ve VIKOR yöntemlerine ilişkin teorik açıklamalara değinilmiştir. Dördüncü bölümde kablo sektöründe faaliyet gösteren on işletme üzerinde gerçekleştirilen uygulamaya ve son bölümde ise sonuç ve bulguların yorumlanmasına yer verilmiştir.

\section{LITERATÜR ÖZETI}

Çalışmanın yukarıda ortaya konan amacı dikkate alındığında literatür özeti temel olarak iki alt bölümden oluşturulmuştur. Illk bölümde tedarikçi seçiminde dikkate alınan kriterler incelenmiştir. İkinci bölümde ise tedarikçi seçimi çalışmalarında kullanılan Çok Kriterli Karar Verme (ÇKKV) teknikleri ortaya konmuştur.

\subsection{Tedarikçi Seçimi}

Literatürde tedarikçi seçimi ile ilgili çok sayıda çalışma yapılmıştır. Yapılan çalışmalarda birçok farklı kriter kullanılmıştır. Bununla birlikte faydalanılan kriterler Tablo-1'deki şekilde özetlenebilir. Buna göre, tedarikçi seçimi çalışmalarında araştırmacıların sıklıkla kullandıkları kriterler; fiyat, kalite ve teslimattır. Bunun yanı sıra birden çok unsurun (finansal, teknik ve işletim) başarı ile yürütülmesi de önemli bir kriter olarak dikkati çekmektedir.

Tablo 1: Tedarikçi Seçim Kriterleri

\begin{tabular}{|c|c|}
\hline Kriter & Yazar / Çalışma \\
\hline Fiyat & $\begin{array}{l}\text { Dickson (1966), Evans (1980), Shipley (1985), Mazurak vd. (1985), Venkatraman ve Ramanujam (1986), Weber vd. } \\
\text { (1991), Pi ve Low (2006). }\end{array}$ \\
\hline Kalite & $\begin{array}{l}\text { Dickson (1966), Evans (1980), Shipley (1985), Mazurak vd. (1985), Venkatraman ve Ramanujam (1986), Ellram (1990), } \\
\text { Weber vd. (1991), Chao vd. (1993), Barbarosoglu ve Yazgac (1997), Dağdeviren ve Eren (2001), Chan ve Chan (2004), } \\
\text { Tseng ve Lin (2005), Pi ve Low (2006). }\end{array}$ \\
\hline Teslimat & $\begin{array}{l}\text { Dickson (1966), Evans (1980), Shipley (1985), Mazurak vd. (1985), Venkatraman ve Ramanujam (1986), Ellram (1990), } \\
\text { Weber vd. (1991), Chao vd. (1993), Chan ve Chan (2004), Liu ve Hai (2005), Pi ve Low (2006). }\end{array}$ \\
\hline $\begin{array}{l}\text { Finansal, } \\
\text { Teknik ve } \\
\text { İşletim Başarısı }\end{array}$ & $\begin{array}{l}\text { Beck ve Lin (1981), Arbel ve Seidmmann (1984, 1985), Mazurak vd. (1985), Bard (1986), Arbel ve Seidmmann (1990), } \\
\text { Zviran, (1993), Barbarosoglu ve Yazgac (1997), Ghodsypur ve O'Brien (1998). }\end{array}$ \\
\hline Maliyet & Venkatraman ve Ramanujam (1986), Dağdeviren ve Eren (2001), Chan ve Chan (2004). \\
\hline Esneklik & Chan ve Chan (2004), Tseng ve Lin (2005). \\
\hline Servis & Chan ve Chan (2004), Pi ve Low (2006). \\
\hline Teknoloji & Dağdeviren ve Eren (2001), Tseng ve Lin (2005). \\
\hline $\begin{array}{l}\text { Üretim } \\
\text { Kapasitesi }\end{array}$ & Dickson (1966), Yurdakul ve i̇ç (2001). \\
\hline Yönetsel Beceri & Yurdakul ve İç (2001), Liu ve Hai (2005). \\
\hline Yenilik & Chan ve Chan (2004). \\
\hline Kusurlu Ürün & Venkatraman ve Ramanujam (1986). \\
\hline İletişim Araçları & Dickson (1966), Tseng ve Lin (2005). \\
\hline
\end{tabular}

\subsection{Tedarikçi Seçiminde Çok Kriterli Karar Verme Yöntemleri}

Tedarikçi seçimi kararları farklı kriterlerin değerlendirilmesini içerdiğinden çok kriterli bir karar problemi olarak değerlendirilmektedir (Ho vd., 2010). Tedarikçi seçiminde kalite, fiyat, teslimat ve esneklik gibi çok sayıda nitel ve nicel kriter bulunduğundan seçim süreci birçok kriteri içermelidir. Çok Kriterli Karar Verme (ÇKKV) yöntemleri birbiriyle çelişen ve çok sayıda kriter içeren problemler için çözüm önerisi sunduğundan bu tür problemlerin çözümünde sıklıkla kullanılmaktadır. Ölçülebilen ve ölçülemeyen çok sayıda faktörü eş zamanlı değerlendirme imkânı sağlayan ÇKKV yöntemlerinin kullanılması, karar vericilere doğru alternatifin seçiminde yardımcı olmaktadır.

Literatürde ÇKKV yöntemleri kullanılarak gerçekleştirilen çok sayıda tedarikçi seçimi uygulaması mevcuttur. Bu çalışmalarda yaygın olarak Analitik 
Hiyerarşi Süreci-AHS (Nydick ve Hill, 1992; Yahya ve Kingsman,1999; Bhutta ve Huq, 2002; Muralidharan vd., 2002; Chan, 2004; Chan ve Chan, 2004; Liu ve Hai, 2005; Xia ve Wu, 2007; Chan vd., 2007; Hou ve Su, 2007; Sevkli vd., 2008; Akarte vd., 2011), Analitik Ağ Süreci-AAS (Sarkis ve Talluri, 2002; Bayazit, 2006; Gencer ve Gürpinar, 2007; Demirtas ve Üstün, 2008; Hsu ve Hu, 2009), Decision Making Trial And Evaluation Laboratory-DEMATEL (Hsu vd., 2013), Gri ilişkisel Analiz-GIA (Li vd., 2007), Veri Zarflama Analizi-VZA (Liu vd., 2000; Talluri ve Sarkis, 2002; Garfamy, 2006; $\mathrm{Wu}, 2009 a)$ ), Matematiksel Programlama (Kermani vd., 2011), Simple Multi-Attribute Rating TechniqueSMART (Barla, 2003; Huang ve Keska, 2007), Elimination and Choice Expressing Reality-ELECTRE (Boer vd.,1998), Technique for Order Preference by Similarity to Ideal Solution-TOPSIS (Jadidi vd, 2010; Vimal vd, 2012), Preference Ranking Organization Method for Enrichment of Evaluations-PROMETHEE (Dulmin ve Mininno, 2003; Dağdeviren ve Eraslan, 2008) ve Vlšekriterijumsko KOmpromisno Rangiranje-VIKOR (Jianxun vd., 2007) gibi ÇKKV yöntemleri kullanılmaktadır.

Bununla birlikte ÇKKV yöntemlerinin birlikte kullanımı ile gerçekleştirilen çalışmaların varlığı da dikkati çekmektedir. Buna göre; AHS-TOPSIS (Lin vd., 2008; Wang vd., 2009; Guang vd., 2010; Bagheri ve Tarokh, 2010; Supçiller ve Çapraz, 2011; Shahroudi vd., 2011; Fazlollahtabar vd., 2011; Bhutia and Phipon, 2012), AHS-VIKOR (Yılmaz, 2012; Ağırgün, 2012; Tayyar ve Arslan, 2013), AAS-VIKOR (Göktürk vd., 2011; Görener, 2011), AAS-TOPSIS (Önüt vd., 2009; Shahroudi ve Rouydel, 2012), AHS-VZA (Ramanathan, 2007; Sevkli vd., 2007), AHS-GIA (Yang ve Chen, 2006), AHS-DEMATEL (Raut vd., 2011) ve AAS-DEMATEL (Shen vd., 2012) gibi bütünleşik yöntem uygulamaları ile tedarikçi seçimi üzerine çalışmalar da söz konusudur.

Yukarıdaki çalışmalara ek olarak bulanık mantık yaklaşımı kullanılarak ÇKKV yöntemlerinin kullanıldığı çalışmaların da özellikle son dönemde arttığı görülmektedir. Buna göre; Bulanık AHS (Kahraman vd., 2003; Akman ve Alkan, 2006; Chan vd., 2008; Seçme ve Özdemir, 2008; Lee, 2009; Lee vd., 2009), Bulanık TOPSIS (Chen vd., 2006; Boran vd., 2009; Deng ve Chan, 2011), Bulanık SMART (Chou ve Chang, 2008), Bulanık VIKOR (Sanayei vd., 2010; Shemshadi vd., 2011; Akyüz, 2012; Datta vd., 2012), Bulanık GíA (Wu, 2009b), Bulanık DEMATEL (Chang vd., 2011; Gharakhani, 2012) ve Bulanık ELECTRE (Şevkli, 2010) yöntemi kullanılarak tedarikçi seçimi uygulaması gerçekleştirilmektedir.

Yukarıda ortaya konan literatür incelendiğinde tedarikçi seçimi problemlerinde ÇKKV yöntemlerinin yaygın olarak kullanıldığı görülmektedir. Bu çalışmaların bir kısmında yalnızca bir yöntem kullanılırken bir kısmında ise iki yöntem bütünleşik olarak kullanılmıştır. Bununla birlikte tedarikçi seçim problemi uygulamaları kapsamında DEMATEL-AAS-VIKOR yöntemlerinin bütünleşik olarak kullanıldığı bir çalışmaya rastlanıımamıştır. Çalışmanın bu yönden literatürdeki önemli bir boşluğu doldurması beklenmektedir.

\section{YÖNTEM}

Temel amacl, kablo sektöründe tedarikçi seçimi faaliyetinin gerçekleştirilmesi olan bu çalışmanın uygulama aşamasında üç temel yöntemden faydalanılmıştır. Bu kapsamda kriter ilişkilerinin belirlenmesinde DEMATEL, kriter ağırlıklarının tespitinde AAS ve tedarikçi seçiminde ise VIKOR yöntemleri kullanılmıştır. Bu yöntemlere ilişkin teorik açıklamalar aşağıda verilmiş̧ir.

\subsection{DEMATEL}

Shieh vd. (2010), DEMATEL (Decision Making Trial And Evaluation Laboratory) yöntemini, karmaşık ve iç içe geçmiş problem gruplarının çözümü için kullanılan çok kriterli bir karar verme yöntemi olarak tanımlamıştır. Lin vd. (2009)'a göre DEMATEL, kriterlerin birbirleri arasındaki ilişkilerinin belirlenmesinde hangilerinin etkileyen hangilerinin etkilenen olduğunu tespit etmekte ve buna dayalı olarak bir ilişki ağı oluşturulmasına imkân tanımaktadır. Bu nedenlere dayalı olarak çalışmada kriterlerarası ilişkilerin belirlenmesinde DEMATEL yöntemi kullanıımıştır.

Günümüzde birçok konudaki karmaşık sorunların incelenmesinde yaygın olarak kullanılan DEMATEL yöntemi, Cenevre Battelle Memorial Enstitüsü tarafından geliştirilmiştir (Fontela ve Gabus, 1974; 1976). Yöntemin uygulanması temel olarak dört adımdan oluşmaktadır (Lin vd., 2009; Tsai ve Chou, 2009; Aksakal ve Dağdeviren, 2010; Sevim vd., 2011): Illk olarak uzman bir grup tarafından ikili karşılaştırma ölçeği (0-etkisiz, 1-düşük etki, 2-orta etki, 3-yüksek etki ve 4-çok yüksek etki) yardımıyla ortaya konulan direkt etki matrisi (A) oluşturulmaktadır. Ardından direkt etki matrisindeki değerlerin bu matrisin satır ve sütunlarındaki en küçük değer (z) kullanılarak normalize edilmesi ile oluşturulan normalleştirilmiş direkt etki matrisi (N) gelmektedir. Üçüncü aşamada normalleştirilmiş direkt etki matrisinin birim matris (I) ile işleme sokulması $\left[\mathrm{T}=\mathrm{N} \times(1-\mathrm{N})^{-1}\right]$ ile toplam etki matrisi $(T)$ oluşturulmaktadır. Dördüncü ve son adımda ise toplam etki matrisindeki satırlar toplamı (R) ve sütunlar toplamı (C) kullanılarak hesaplanan $\mathrm{R}-\mathrm{C}$ ve $\mathrm{R}+\mathrm{C}$ değerleri yardımıyla gönderici ve alıcı gruplar belirlenmektedir. $\mathrm{Bu}$ noktada, pozitif R-C değerine sahip kriterlerin diğerleri üzerinde daha yüksek etkiye sahip oldukları kabul 
edilir ve bu kriterler gönderici olarak adlandırılır. R-C değeri negatif olan ve alıcı olarak adlandırılan kriterlerin ise, diğer kriterlerden daha fazla etkilendiği kabul edilir. Diğer taraftan $\mathrm{R}+\mathrm{C}$ değerleri, her bir kriterin diğer kriterlerle arasındaki ilişkiyi gösterir ve $\mathrm{R}+\mathrm{C}$ değeri yüksek olan kriterlerin diğer kriterlerle daha fazla ilişkiye sahip olduğu kabul edilir.

\subsection{AAS}

Thomas L. Saaty tarafından geliştirilen AAS (Analitik Ağ Süreci), karar verme sürecinde etkili olan tüm kriter ve alt kriterler arasındaki ilişkileri dikkate almak suretiyle kriterler arası ilişkileri ağ modeli kurarak çözümleyen bir yöntemdir (Saaty ve Vargas, 2006; Saaty, 2009). AAS yöntemi, gruplar arası ve grup içi bağımlılıkların yanı sıra kriterler arasındaki geri bildirimleri dikkate alması (Dağdeviren ve Yüksel, 2007) dolayısıyla karar verme problemlerine gerçekçi çözümler sağlamaktadır. Bunun yanı sıra Jharkharia ve Shankar (2007)'ye göre AAS kullanıcılara; (i) nicel ve nitel kriterleri hiyerarşik bir yapıya bağlı olma zorunluluğu olmadan modele dâhil edebilmesi, (ii) öncelikleri belirleyerek amaç ile kriterler arasında bağlantı kurması ve (iii) öncelikleri oransal bir ölçekle belirlemesi şeklinde birçok avantaj sağlamaktadır. Bu nokrada AAS uygulama süreci, temel olarak dört aşamadan meydana gelmektedir (Saaty ve Vargas, 2006; Gencer ve Gürpinar, 2007; Tuzkaya vd., 2008; Saaty, 2009; Ar, 2013):

1.Adım: Karar Problemine Ait Modelin Oluşturulması: Yöntemin ilk aşamasında kriterler, alt kriterler ve alternatifler belirlenir. Ardından tüm bu unsurlar arasındaki ilişkileri gösteren ağ yapısı oluşturulur.

2.Adım: Ağırlıklandırılmamış Süpermatrisin Oluşturulması: Ağ modelinin içinde yer alan ikili ilişkiler, karar vericiler tarafından Saaty (2000)'nin geliştirdiği ölçek (1: Eşit derecede önemli, 3: Çok az derecede önemli, 5: Kuvvetli derecede önemli, 7: Çok kuvvetli derecede önemli, 9: Aşırı derecede önemli, 2-4-6-8: Ara değerler) kullanılarak değerlendirilir ve tüm ikili karşılaştırmaların yer aldığı Ağılıklandııılmamış Süpermatris oluşturulur.

3.Adım: Ağırıklandırılmış Süpermatrisin Oluşturulması: Bu aşamada; ağırlıklandırılmamış süper matristeki değerler ilgili alt kriteri barındıran kriterin ağırlığıyla çarpılır ve Ağırlıklandırılmış Süpermatris elde edilir.

4.Adım: Limit Süpermatrisin Oluşturulması: Üçüncü aşama sonunda elde edilen Ağırlıklandırılmış Süpermatris'in, satırları aynı değere ulaşıncaya kadar büyük dereceden kuvveti alınarak Limit Süpermatris elde edilir. Limit Süpermatris'teki sütunların normalleştirilmesiyle alternatiflerin öncelik değerleri belirlenir.

\subsection{VIKOR}

Opriovic ve Tzeng (2004) tarafından geliştirilen VIKOR (Vlšekriterijumsko KOmpromisno Rangiranje) yöntemi, alternatifler ışığında ve değerlendirme kriterleri kapsamında uzlaşık çözüm belirlemeyi amaçlayan bir ÇKKV problemi çözüm yöntemidir. Bu uzlaşık çözüm, ideal çözüme en yakın çözüm olarak ortaya çıkmaktadır. VIKOR yöntemi genel olarak aşağıdaki adımların izlenmesi ile uygulanmaktadır (Opriovic ve Tzeng, 2004; Opriovic ve Tzeng, 2007; Görener, 2011; Liou vd., 2011):

1.Adım: En İyi ve En Kötü Değerlerin Belirlenmesi: Her bir kriter için en iyi $\left(f_{i}^{+}\right)$ve en kötü $\left(f_{i}^{-}\right)$ değerler belirlenir. Eğer kriter fayda kriteri ise (1), maliyet kriteri ise (2) eşitlikleri kullanılır.

$$
\begin{array}{ccc}
f_{i}^{+}=\max _{j} f_{i j} & f_{i}^{-}=\min _{j} f_{i j} & i=1,2, \ldots, n \\
f_{i}^{+}=\min _{j} f_{i j} & f_{i}^{-}=\max _{j} f_{i j} & i=1,2, \ldots, n
\end{array}
$$

2.Adım: $S_{j}$ ve $R_{j}$ Değerlerinin Hesaplanması: Her bir alternatif için $S_{j}$ (3) ve $R_{j}$ (4) değerleri hesaplanır. $w_{i}$, kriter ağırlıklarını ifade etmektedir.

$$
\begin{aligned}
& S_{j}=\sum_{k=1}^{n} w_{i}\left(f_{i}^{+}-f_{i j}\right) /\left(f_{i}^{+}-f_{i}^{-}\right) \\
& R_{j}=\max \left[w_{i}\left(f_{i}^{+}-f_{i j}\right) /\left(f_{i}^{+}-f_{i}^{-}\right)\right]
\end{aligned}
$$

3. Adım: $Q_{j}$ Değerlerinin Hesaplanması: Her bir alternatif veya değerlendirme birimi için $Q_{j}$ (5) değerleri hesaplanır.

$$
Q_{j}=\frac{v\left(S_{j}-S^{+}\right)}{\left(S^{-}-S^{+}\right)}+\frac{(1-v)\left(R_{j}-R^{+}\right)}{\left(R^{-}-R^{+}\right)}
$$

Denklem (5)'te, $S^{+}=\min _{j} S_{j} ; S^{-}=\max _{j} S_{j}$ ; $R^{+}=\min _{j} R_{j} ; R^{-}=\max _{j} R_{j}$ değerlerini ifade etmektedir. $v$ değeri, maksimum grup faydasını sağlayan strateji için ağırlığı ifade ederken, $(1-v)$ değeri karşıt görüştekilerin minimum pişmanlığının ağırlığını ifade etmektedir. Genellikle $v=0,5$ kullanilır.

4.Adım: $Q_{j}$, ve $R_{i}$ Değerlerinin Sıralanması: Elde edilen $Q_{j}$, $S_{j}$ ve $R_{j}$ değerleri sıralanır. En küçük $Q_{j}$ değerine sahip alternatif en iyi seçenek olarak ifade edilir.

5.Adım: Sonuçların Geçerliliğinin Test Edilmesi: Elde edilen sonucun geçerliliği iki koşul kontrol edilerek test edilir. Bu koşullar, şu şekilde ifade edilebilir:

Koşul 1 - Kabul Edilebilir Avantaj: En iyi ve en iyi ikinci seçenek arasında belirgin bir fark olduğunun kanıtlanmasını içeren koşuldur. (6) numaralı eşitsizlikte $A^{\prime}$ en küçük $Q$ değerine sahip olan birinci en iyi alternatif, $A$ " ise ikinci en iyi alternatiftir. $D(Q)$ değeri (7) numaralı eşitlikte belirtildiği şekilde alternatif sayısı ( 
$j$ ) kullanılarak hesaplanır.

$$
\begin{aligned}
& Q_{A^{\prime}}-Q_{A^{\prime \prime}} \geq D(Q) \\
& D(Q)=1 /(j-1)
\end{aligned}
$$

Koşul 2 - Kabul Edilebilir Istikrar: Elde edilen uzlaşık çözümün istikrarlı olduğunun kanıtlanması açısından en küçük $Q$ değerine sahip $k$ alternatifi, $S$ ve $R$ değerlerinin en az bir tanesinde de en küçük skoru elde etmiş olmalıdır.

Belirtilen iki koşuldan bir tanesi sağlanamazsa bir uzlaşık çözüm kümesi önerilir. Bu uzlaşık çözüm kümesi;

- Sadece Koşul 2 sağlanmazsa $A^{\prime}$ ve $A^{\prime \prime}$ alternatiflerinden,

- Koşul 1 sağlanmazsa $A^{\prime}, A^{\prime \prime}, \ldots, A^{M}$ alternatiflerinden oluşur.

$A^{M}$ alternatifi $Q_{A^{M}}-Q_{A^{\prime}}<D(Q)$ eşitsizliğini sağlayan en büyük $\mathrm{M}$ değeri şeklinde belirlenir. Uzlaşık çözüm kümesi dahilinde $Q$ değerlerine göre sıralama yapılır. En iyi alternatif, en düşük $Q$ değerine sahip alternatiflerden biridir.

\section{UYGULAMA}

Küreselleşme ile birlikte haberleşme gereksinimi arttıkça, iletişim teknolojileri de gelişmektedir. Teknoloji geliştikçe ve yaygınlaştıkça, teknolojik bilgiyi iletme yöntemleri için gerekli altyapıdan beklenen hizmet kalitesi de sürekli değişmektedir. Bu altyapının ana bileşenini de kablo oluşturmaktadır. Kablo, günlük hayatta kullanılan hemen her üründe gerekli bir parça olup, büyük enerji nakil kablolarından, haberleşme kablolarına kadar çok geniş bir kullanım alanına sahiptir.

Bu çalışmada gelişen ve değişen teknolojilerin yayılması açısından önemi artan kablo tedarikçileri değerlendirilmiştir. Uygulama kapsamında ise haberleşme kablolarına ait polietilen tedarikçi seçimi gerçekleştirilmiştir. Bu kapsamda polietilen tedarikçileri Firma 1, Firma 2 ve Firma 3 olarak adlandırılmış olup, söz konusu firmalar uluslararası pazarda faaliyet göstermektedir. Firmaların tamamı çokuluslu firmalar olup, Firma 1 Amerika Birleşik Devletleri, Firma 2 Avrupa ve Firma 3 Uzak Doğu kökenlidir. Yıllık satış hacimleri açısından değerlendirildiğinde Firma 1, Firma 2 ve Firma 3'e göre daha yüksek değerlere sahiptir.

\subsection{DEMATEL Yöntemi ile Hiyerarşik Yapının Oluşturulması}

DEMATEL yöntemi kullanılarak, tedarikçi seçim kriterleri arasındaki ilişkilerin belirlenmesi aşamasında öncelikle direkt etki matrisi oluşturulmuştur. Bunun için 10 kişilik bir uzman gruptan destek alınmış- tır. Bu kapsamda, kablo sektöründe faaliyet gösteren 10 işletmenin her birinden birer personel (satın alma veya teknik) belirlenmiştir. Bu kişiler ile yüz yüze görüşülmüş ve her bir uzman için ayrı bir direkt etki matrisi oluşturulmuştur. Her bir firma için $5 \times 5$ ana kriter, $17 \times 17$ alt kriter matrisi oluşturulmuştur. Oluşturulan matrislerin geometrik ortalaması alınarak Direkt Etki Matrisi (A) elde edilmiştir.

Direkt Etki Matrisi (A) oluşturulduktan sonra yukarıda gösterilen formüller yardımıyla normalize edilmiş matrise $(\mathrm{N})$ ulaşılmıştır. Son aşamada ise normalize matris, yukarıda belirtilen formüller yardımıyla toplam etki matrisine $(T)$ dönüştürülmüştür. Gerçekleştirilen her bir aşama sonucunda elde edilen sonuçlar Ek-1'de verilmiştir.

Toplam etki matrisleri düzenlendikten sonra satır ve sütun toplam ve farklarına bağlı olarak $R+C$ ve $\mathrm{R}-\mathrm{C}$ değerleri hesaplanmıştır. Bu değerler yardımıyla her bir kriterin $\mathrm{R}+\mathrm{C}$ ve $\mathrm{R}-\mathrm{C}$ değerlerini elde edilmiştir (Tablo-2).

\begin{tabular}{|c|c|c|c|c|}
\hline $\begin{array}{c}\text { Kriter } \\
\text { No }\end{array}$ & Kriter Açıklaması & $\mathbf{R}+\mathbf{C}$ & R-C & \\
\hline $\mathbf{M}$ & Maliyet & 2,1314 & $-1,4095$ & Alıcı \\
\hline $\mathbf{K}$ & Kalite & 2,0786 & 0,2792 & Gönderici \\
\hline $\mathbf{T}$ & Teslimat & 1,8005 & $-0,2417$ & Alıcı \\
\hline $\mathbf{Y}$ & Yenilik & 1,6971 & 0,5952 & Gönderici \\
\hline $\mathbf{E}$ & Esneklik & 1,8804 & 0,7768 & Gönderici \\
\hline M1 & Ürün Fiyatının Uygunluğu & 1,7964 & $-1,1636$ & Alıcı \\
\hline M2 & Fiyat İskontosu & 1,6150 & $-0,8210$ & Alıcı \\
\hline M3 & Ödeme Vadesi & 0,6304 & $-0,2569$ & Alıcı \\
\hline K1 & Ürün Kalitesi / Güvenilirliği & 1,3316 & 0,6344 & Gönderici \\
\hline K2 & Hatalı Ürün Yüzdesi & 1,9110 & 0,6283 & Gönderici \\
\hline K3 & Kalite Sertifikası & 1,1465 & 0,1912 & Gönderici \\
\hline T1 & Zamanında Teslimat & 1,1973 & $-0,6104$ & Alıcı \\
\hline T2 & Teslimat Hızı & 1,1726 & $-0,3894$ & Alıcı \\
\hline T3 & Doğru Miktarda Teslimat & 0,4272 & $-0,3146$ & Alıcı \\
\hline T4 & Uygun Ambalaj / Paketleme & 0,9125 & 0,2924 & Gönderici \\
\hline E1 & $\begin{array}{l}\text { Ürün Miktarındaki Değişimlere } \\
\text { Cevap Verebilme }\end{array}$ & 0,9319 & 0,1343 & Gönderici \\
\hline E2 & $\begin{array}{l}\text { Ürün Çeşitliliğindeki Değişimlere } \\
\text { Cevap Verebilme }\end{array}$ & 1,0161 & $-0,2300$ & Alıcı \\
\hline E3 & $\begin{array}{l}\text { Ürün Tasarımdaki Değişimlere } \\
\text { Cevap Verebilme }\end{array}$ & 1,1561 & 0,1159 & Gönderici \\
\hline E4 & Teslimat Zamanındaki Esneklik & 0,8705 & $-0,0087$ & Alıcı \\
\hline Y1 & $\begin{array}{l}\text { Yeni Ürün Geliştirme Sürecine } \\
\text { Katılım }\end{array}$ & 1,2760 & 0,5952 & Gönderici \\
\hline Y2 & Teknik Problem Çözme Yeteneği & 1,2540 & 0,4732 & Gönderici \\
\hline Y3 & Bilgi ve Teknoloji Paylaşımı & 1,2802 & 0,7297 & Gönderici \\
\hline
\end{tabular}

Tablo 2: Her Bir Kritere Illişkin R+C ve R-C Değerleri 


\subsection{AAS ile Kriter Ağırlıklarının Belirlenmesi}

Bu uygulama kapsamında AAS yönteminin ilk aşaması olan ağ yapısının oluşturulması süreci, DEMATEL yöntemi ile tamamlanmıştır. Bu nedenle AAS uygulaması için öncelikle DEMATEL uygulaması sonucunda elde edilen Toplam Etki Matrisi'nden hareketle Ağır- lıklandırılmamış Süpermatris oluşturulmuştur. İkinci aşamada bu matristen hareketle Ağırlıklandırılmış Süpermatris oluşturulmuştur. Son olarak Limit Süpermatris oluşturulmuş ve AAS uygulaması tamamlanmıştır. Elde edilen tüm matrisler Ek-2'de verilmiştir. Bu sonuçlara göre her bir kritere ilişkin ağırlıklar ise Tablo3'te ortaya konmuştur.

Tablo 3: Kriter Ağırlıkları

\begin{tabular}{|l|cl|c|}
\hline Ana Kriter & Alt Kriter & Ağırlık \\
\hline Maliyet/Fiyat & M1 Ürün Fiyatının Uygunluğu & 0,147 \\
\hline & M2 & Fiyat İskontosu & 0,128 \\
\hline & M3 & Ödeme Vadesi & 0,047 \\
\hline Kalite & K1 & Ürün Kalitesi / Güvenilirliği & 0,048 \\
\hline & K2 $\quad$ Hatalı Ürün Yüzdesi & 0,073 \\
\hline & K3 $\quad$ Kalite Sertifikası & 0,058 \\
\hline Teslimat & T1 & Zamanında Teslim & 0,093 \\
\hline & T2 & Teslimat Hızı & 0,063 \\
\hline & T3 & Doğru Miktarda Teslimat & 0,025 \\
\hline & T4 & Uygun Ambalaj / Paketleme & 0,032 \\
\hline & E1 & Ürün Miktarındaki Değişimlere Cevap Verebilme & 0,035 \\
\hline & E2 & Ürün Çeşitliliğindeki Değişimlere Cevap Verebilme & 0,036 \\
\hline & E3 & Ürün Tasarımdaki Değişimlere Cevap Verebilme & 0,034 \\
\hline & E4 & Teslimat Zamanındaki Esneklik & 0,037 \\
\hline Yenilik & Y1 $\quad$ Yeni Ürün Geliştirme Sürecine Katılım & 0,049 \\
\hline & Y2 & Teknik Problem Çözme Yeteneği & 0,051 \\
\hline & Y3 $\quad$ Bilgi ve Teknoloji Paylaşımı & 0,044 \\
\hline
\end{tabular}

\subsection{VIKOR ile Tedarikçi Seçimi}

VIKOR yöntemi ile karar probleminin çözümünde Tablo 3'teki alt kriter ağırlıkları kullanılmıştır. Bu noktada karar vericilerden her bir alternatifi her bir kriter açısından değerlendirmesi istenmiş ve ardından karar vericilerin verdikleri cevapların geometrik ortalamaları alınmıştır. Sonuçta alternatiflerin her bir alt kriter için aldığı değerleri ve kriter ağırlıklarını içeren karar matrisi (Tablo 4) oluşturulmuştur.

Tablo 4: Kriter Ağırlıkları ve Karar Matrisi

\begin{tabular}{|c|c|c|c|c|c|c|c|c|c|c|c|c|c|c|c|c|c|}
\hline & M1 & M2 & M3 & K1 & K2 & K3 & T1 & T2 & T3 & T4 & E1 & E2 & E3 & E4 & Y1 & Y2 & Y3 \\
\hline FiRMA 1 & 2,29 & 2,00 & 3,63 & 4,00 & 4,00 & 4,00 & 3,63 & 3,63 & 4,00 & 3,63 & 4,00 & 3,63 & 4,00 & 4,00 & 4,00 & 4,00 & 3,00 \\
\hline FiRMA 2 & 2,00 & 2,00 & 3,63 & 3,63 & 4,00 & 4,00 & 2,00 & 2,00 & 3,63 & 3,00 & 2,00 & 2,00 & 2,29 & 2,29 & 2,00 & 3,00 & 2,00 \\
\hline FiRMA 3 & 3,63 & 3,30 & 3,00 & 2,29 & 2,00 & 3,00 & 3,00 & 3,00 & 3,00 & 2,62 & 3,00 & 2,00 & 2,00 & 2,00 & 2,00 & 2,00 & 1,26 \\
\hline Ağırlık & 0,147 & 0,128 & 0,047 & 0,048 & 0,073 & 0,058 & 0,093 & 0,063 & 0,025 & 0,032 & 0,035 & 0,036 & 0,034 & 0,037 & 0,049 & 0,051 & 0,044 \\
\hline
\end{tabular}

Karar matrisine dayalı olarak alternatiflerin aldığı en iyi ( $\left.f^{+}\right)$ve en kötü (f) değerler, kriterlerin hepsi faydayı temsil ettiği için eşitlik (1) yardımıyla hesaplanmış ve Tablo 5 oluşturulmuştur.

Tablo 5: Kriter Bazında En İyi ve En Kötü Değerler

\begin{tabular}{|c|c|c|c|c|c|c|c|c|c|c|c|c|c|c|c|c|c|}
\hline & M1 & M2 & M3 & K1 & K2 & K3 & T1 & T2 & T3 & T4 & E1 & E2 & E3 & E4 & Y1 & $\mathrm{Y2}$ & Y3 \\
\hline $\mathbf{f}^{+}$ & 3,63 & 3,30 & 3,63 & 4,00 & 4,00 & 4,00 & 3,63 & 3,63 & 4,00 & 3,63 & 4,00 & 3,63 & 4,00 & 4,00 & 4,00 & 4,00 & 3,00 \\
\hline$f$ & 2,00 & 2,00 & 3,00 & 2,29 & 2,00 & 3,00 & 2,00 & 2,00 & 3,00 & 2,62 & 2,00 & 2,00 & 2,00 & 2,00 & 2,00 & 2,00 & 1,26 \\
\hline
\end{tabular}

Bir sonraki aşamada; eşitlik (3), (4) ve (5)'ten yararlanılarak sırasıyla $S j, R j$ ve $Q j$ değerleri hesaplanmıştır. Qj değerinin hesaplanmasında öncelikle literatürde sıklıkla kullanılan $v=0,5$ ağırlığı dikkate alınmıştır. Ardından Tablo 6'dan da görülebileceği gibi maksimum grup faydasının çözüm üzerindeki etkisinin ölçülebilmesi için problemin farklı $v$ değerleri için çözümü he- saplanmıştır. Buna göre; hesaplamada kullanılan tüm $v$ değerleri için Firma 2 en iyi uzlaşık çözüm olarak belirlenmiştir. Sonuçların geçerliliğinin testi için Koşul 1 ve Koşul 2'nin gerçekleşme durumuna bakılmıştır. Buna göre Koşul 1 sağlanırken Koşul 2 sağlanamamıştır. Bu durumda karar problemi için uzlaşık çözüm kümesi, Firma 2 ve Firma 3'ten oluşmaktadır. 
Tablo 6: VIKOR Sonuçları

\begin{tabular}{|c|c|c|c|c|c|c|c|c|}
\hline & $\mathbf{S}_{\mathbf{j}}$ & $\mathbf{R}_{\mathbf{j}}$ & $\mathbf{Q}(\mathbf{v}=\mathbf{0 , 2})$ & $\mathbf{Q}(\mathbf{v}=\mathbf{0 , 4})$ & $\mathbf{Q}(\mathbf{v}=\mathbf{0 , 5})$ & $\mathbf{Q}(\mathbf{v}=\mathbf{0}, \mathbf{6})$ & $\mathbf{Q}(\mathbf{v}=\mathbf{0 , 8})$ & $\mathbf{Q}(\mathbf{v}=\mathbf{1})$ \\
\hline FiRMA 1 & 0,249 & 0,128 & 1,834 & 1,691 & $\mathbf{1 , 6 1 9}$ & 1,547 & 1,404 & 1,260 \\
\hline FiRMA 2 & 0,701 & 0,147 & 1,582 & 1,187 & $\mathbf{0 , 9 8 9}$ & 0,791 & 0,396 & 0,000 \\
\hline FiRMA 3 & 0,612 & 0,073 & 1,822 & 1,665 & $\mathbf{1 , 5 8 7}$ & 1,509 & 1,353 & 1,196 \\
\hline
\end{tabular}

\section{SONUÇ ve ÖNERILER}

İşletmeler, stratejik hedeflerine ulaşabilmek için yoğun rekabet ortamında rakiplerine üstünlük sağlayarak müşteri beklentilerini karşılamak zorundadır. Bu nedenle nihai ürünü meydana getiren hammaddeleri ve/veya yarı mamulleri doğru zamanda ve işletme çıkarlarına uygun şartlarla doğru tedarikçilerden temin etmelidirler. Bu açıdan bakıldığında tedarikçi seçim süreci, işletmeler için oldukça önemli ve kritik bir süreç olarak değerlendirilmektedir. Karar verme teknikleri, işletmenin tedarikçiden beklentisi ile tedarikçinin sahip olduğu özelliklere göre işletme için en uygun tedarikçiyi belirlemek suretiyle seçim sürecine katkıda bulunmaktadır.

ÇKKV, birden fazla ve birbiriyle çelişen kriterlerin oluşturduğu problemlerin çözümü olarak tanımlanabilir. İşletmelerin amaç ve hedefleri doğrultusunda karar vericiler, birden fazla ve kimi zaman birbiriyle çelişen kriterler doğrultusunda karar vermek zorunda kalabilmektedir.

Kablo sektöründe polietilen tedarikçi seçimini amaçlayan bu çalışmada öncelikle seçim kriterleri belirlenmiştir. Ardından sırasıyla kriterler arası ilişkinin saptanması amacıyla DEMATEL, kriter ağırlıklarının belirlenmesi amacıyla AAS ve elde edilen veriler ışığında tedarikçi seçimi için VIKOR uygulaması gerçekleştirilmiştir.

Yapılan uygulama neticesinde tedarikçi seçiminde en önemli kriterin Ürün Fiyatının Uygunluğu $(0,147)$ olduğu, Fiyat Iskontosu $(0,128)$, Zamanında Teslimat $(0,093)$ ve Hatalı Ürün Yüzdesi $(0,073)$ kriterlerinin de ürün fiyat uygunluğunu takip ettiği ortaya çıkmıştır.

Belirlenen kriterler kullanılarak tedarikçi firmaların VIKOR yöntemi ile sıralanması neticesinde en iyi tedarikçinin Firma 2 olduğu tespit edilmiş, sonuçların geçerliliğinin tespiti için Koşul 1 ve Koşul 2'nin gerçekleşme durumuna bakılmıştır. Yapılan inceleme sonucunda Koşul 1 sağlanırken Koşul 2 sağlanamamıştır. Bu durumda karar problemi için uzlaşık çözüm kümesi, Firma 2 ve Firma 3'ten oluşmuştur. Bir başka ifadeyle firma birden fazla tedarikçi ile çalışmak isitiyorsa tercih edilmesi gereken tedarikçiler Firma 2 ve Firma 3 kodlu tedarikçiler olmalıdır. Benzer bir durum Yılmaz (2012) tarafından yapılan tedarikçi seçimi uygulamasında ve Thipparat ve Thaseepetch (2013) ta- rafından gerçekleştirilen araştırma projesi seçiminde de söz konusu olmuştur.

Bulgular uygulamaya katılan uzman kişiler ile paylaşılmış olup elde edilen sonuçlar işletmelerin uygulamaları ile örtüşmektedir. Uygulama sürecinde analiz edilen işletmeler polietilen tedarikçileri ile sıkı bir iş birliği içerisinde olup, gelecek sipariş dalgalanmalarına karşı optimum stok seviyesinde çalışma gayreti içerisindedirler. Bu nedenle yapılan talep tahminleri neticesinde genellikle çalışma sonucu en iyi tedarikçiler olarak çıkan Firma 2 ve Firma 3'e işletmenin belirlediği oranlarda sipariş geçilerek hem rekabet avantajı sağlanmakta hem de hammadde temininde yaşanabilecek olumsuzluklar en aza indirilmeye çalışılmaktadır. Ancak uygulama yapılan işletmeler kimi zaman değişen piyasa şartlarına, işletme çıkarlarına veya tedarikçi firmanın sağlamış olduğu ayrıcalıklara göre belirtilen tedarikçiler arasından tek tedarikçi ile de çalışmayı tercih edebilmektedirler.

Çalışmada elde edilen bulgular, polietilen tedarikçisi üç firma ile de paylaşılmıştır. Bu doğrultuda Firma 2 ve Firma 3'ün Türkiye pazarında fiyat uygunluğu ve fiyat iskontosu kriterlerini rekabet üstünlüğü sağlayabilecek seviyede kullandığı tespit edilmiştir. Buna karşın Firma 1'in fiyat iskontosu alanında daha rekabetçi olabileceği hususu yetkililere iletilmiştir.

Çalışma kapsamında bilgiler on işletmenin satınalma ve/veya teknik personellerinden oluşan gruptan alınmış olup aynı sektörde faaliyet gösteren diğer firmalar ile görüşsme gerçekleştirilememiştir. Dolayısıyla çalışma sonucu ortaya çıkan bulgular kablo sektöründe faaliyet gösteren firmaların tamamını değil uygulama yapılan on işletmeyi yansıtmakta olup, bu durum çalışmanın kısıtını oluşturmaktadır. Bu nedenle Türkiye'de kablo sektöründe faaliyet gösteren Sanayi ve Ticaret Odası kayıtlı bütün işletmelerin dahil olduğu bir çalışma, sektörü daha net bir biçimde yansıtacak olup, yapılacak çalışma kapsamında elde edilecek bulgular ile Türkiye ve yurtdışı karşılaştırmalı yapılabilecek çalışmalar literatüre katkı sağlayacaktır.

Bu sonuçlar ışığında bütünleşik DEMATEL-AASVIKOR yönteminin kablo sektöründe tedarikçi seçim kriterlerinin ve kriterler arası ilişkinin belirlenmesine ve tedarikçi seçim sürecinde sektör çalışanlarına, literatüre ve yapılacak yeni çalışmalara katkı sağlaması beklenmektedir. 


\section{KAYNAKLAR}

Ağırgün, B. (2012) "Supplier Selection Based on Fuzzy Rough-AHP and VIKOR" Nevşehir Üniversitesi Fen Bilimleri Enstitü Dergisi, 2: 1-11.

Akarte, M.M., Surendra, N.V., Ravi, B. ve Rangaraj, M. (2011) "Web Based Casting Supplier Evaluation Using Analytical Hierarchy Process" Journal of the Operational Research Society, 52: 511-522.

Akman, G. ve Alkan, A. (2006) “Tedarik Zinciri Yönetiminde Bulanık AHP Yöntemi Kullanılarak Tedarikçilerin Performansının Ölçülmesi: Otomotiv Yan Sanayinde Bir Uygulama" Istanbul Ticaret Üniversitesi Fen Bilimleri Dergisi, 5(9):23-46.

Aksakal, E. ve Dağdeviren, M. (2010) “ANP ve DEMATEL Yöntemleri ile Personel Seçimi Problemine Bütünleşik Bir Yaklaşım” Gazi Üniversitesi Mühendislik Mimarlık Fakültesi Dergisi, 25(4): 905-913.

Akyüz, G. (2012) "Bulanık VIKOR Yöntemi ile Tedarikçi Seçimi” Atatürk Üniversitesi IIIBF Dergisi, 26(1): 197-215.

Ar, İ.M. (2013) “Trabzon İli İçin Kentsel Lojistik Stratejisi Seçimi: Birleştirilmiş SWOT Analizi-Analitik Ağ Süreci Yöntemi Uygulaması” II. Ulusal Lojistik ve Tedarik Zinciri Kongresi, 16-18 Mayıs, Aksaray Üniversitesi, Aksaray.

Arbel, A. ve Seidmann A. (1984) "Selecting a Microcomputer for Process Control and Data Acquisition" IIE Transactions, 16(1): 73-80.

Arbel, A. ve Seidmann A. (1985) "Capacity Planning, Benchmarking and Evaluation of Small Computer Systems" European Journal of Operational Research, 22: 347-358.

Arbel, A. ve Seidmann, A. (1990) "An Application of the AHP to Bank Strategic Planning: The Mergers and Acquisitions Process" European Journal of Operational Research, 27: 27-37.

Bagheri, F. ve Tarokh, M.J. (2010) "A Fuzzy Approach for Multi-Objective Supplier Selection” International Journal of Industrial Engineering or Production Research, 21(1): 1-9.

Barbarosoglu, G. ve Yazgac, T. (1997), "An Application of The Analytic Hierarchy Process to the Supplier Selection Problem" Production and Inventory Management Journal, 38(1): 14-21.

Bard, J.F. (1986) "Evaluating Space Station Applications of Automation and Robotics" IEEE Transactions on Engineering Management, 33(2): 102-110.

Barla, S.B. (2003) "A Case Study of Supplier Selection for Lean Supply by Using a Mathematical Model” Logistics Information Management, 16(6): 451-459.

Bayazit, O. (2006) "Use of Analytic Network Process in Vendor Selection Decisions" Benchmarking: An International Journal, 13(5): 566-579.
Beck M.P. ve Lin B.W. (1981) "Selection of Automated Office Systems: A Case Study” OMEGA, 9(2): 169-176.

Bhutia P.W. ve Phipon R. (2012) "Application of AHP and TOPSIS Method for Supplier Selection Problem" IOSR Journal of Engineering, 2(10): 43-50.

Bhutta, K.S. ve Huq, F. (2002) "Supplier Selection Problem: A Comparison of the Total Cost of Ownership and Analytic Hierarchy Process Approaches" Supply Chain Management: An International Journal, 7(3): 126-135.

Boer, de L., Wegen, van der L. ve Telgen,J. (1998) "Outranking Methods in Support of Supplier Selection" European Journal of Purchasing \& Supply Management, 4:109-118.

Boran, F.E., Genç, S., Kurt, M. ve Akay, D. (2009) “A Multi-Criteria Intuitionistic Fuzzy Group Decision Making for Supplier Selection with TOPSIS Method" Expert Systems with Applications, 36(8): 11363-11368.

Chan, F.T.S. (2004) "Interactive Selection Model for Supplier Selection Process: An Analytical Hierarchy Process Approach" International Journal of Production Research, 41(5): 3549-3579.

Chan, F.T.S. ve Chan H.K. (2004) "Development Of The Supplier Selection Model- A Case Study in the Advanced Technology Industry" Proceedings of the Institution of Mechanical Engineers, Part B: Journal of Engineering Manufacture, 218(12): 1807- 1824.

Chan, F.T.S., Chan, H.K., Ip, R.W.L. ve Lau, H.C.W. (2007) "A Decision Support System for Supplier Selection in the Airline Industry" Proceedings of the Institution of Mechanical Engineers, Part B: Journal of Engineering Manufacture, 221(4): 741-758.

Chan, F.T.S., Kumar, N., Tiwari, M.K., Lau, H.C.W. ve Choy, K.L. (2008) "Global Supplier Selection: A Fuzzy-AHP Approach” International Journal of Production Research, 46(14): 3825-3857.

Chang, B., Chang, C-W. ve Wu, C-H. (2011) "Fuzzy DEMATEL Method for Developing Supplier Selection Criteria” Expert Systems with Application, 38(3): 18501858.

Chao, C., Scheuing, E.E. ve Ruch, W.A. (1993) "Purchasing Performance Evaluation: An Investigation of Different Perspectives" International Journal of Purchasing and Materials Management, 29(3): 33-39.

Chen, C.T., Lin, C.T. ve Huang, S.F. (2006) "A Fuzzy Approach for Supplier Evaluation and Selection in Supply Chain Management" International Journal of Production Economics, 102: 289-301.

Chou, S-Y. ve Chang, Y-H. (2008) "A Decision Support System for Supplier Selection Based on A StrategyAligned Fuzzy SMART Approach" Expert Systems with Applications, 34: 2241-2253.

Dağdeviren, M. ve Eren, T. (2001) “Tedarikçi Firma Seçiminde Analitik Hiyerarşi Prosesi ve 0-1 Hedef Programlama Yöntemlerinin Kullanılması" Gazi Üniversitesi Mühendislik ve Mimarlık Fakültesi Dergisi, 16(2): 41-52. 
Dağdeviren, M., Dönmez, N. ve Kurt, M. (2006) "Bir İşletmede Tedarikçi Değerlendirme Süreci İçin Yeni Bir Model Tasarımı ve Uygulaması" Gazi Üniversitesi Mühendislik-Mimarlık Fakültesi Dergisi, 21(2): 247-255.

Dağdeviren, M. ve Yüksel, İ. (2007) "Personnel Selection Using Analytic Network Process" İstanbul Ticaret Üniversitesi Fen Bilimleri Dergisi, 11: 99-118.

Dağdeviren, M. ve Eraslan, E. (2008) "PROMETHEE Sıralama Yöntemi ile Tedarikçi Seçimi" Gazi Üniversitesi Mühendislik Fakültesi Dergisi, 23(1): 69-75.

Datta, S., Samantra, C., Mahapatra, S.S., Banerjee, S. ve Bandyopadhyay, A. (2012) "Green Supplier Evaluation and Selection Using VIKOR Method Embedded in Fuzzy Expert System With Interval-Valued Fuzzy Numbers" International Journal of Procurement Management, 5(5): 647-678.

Demirtas, E.A. ve Üstün, Ö. (2008) "An Integrated Multiobjective Decision Making Process for Supplier Selection and Order Allocation" Omega, 36(1): 76-90.

Deng, Y. ve Chan, F.T.S. (2011) "A New Fuzzy Dempster MCDM Method and Its Application in Supplier Selection" Expert Systems with Applications, 38(8): 9854-9861.

Dickson, G.W. (1966) "An Analysis of Vendor Selection Systems and Decisions" Journal of Purchasing, 2: 5-17.

Dulmin, R. ve Mininno, V. (2003) "Supplier Selection Using A Multi-Criteria Decision Aid Method" Journal of Purchasing and Supply Management, 9(4): 177-187.

Ellram, L.M. (1990) "The Supplier Selection Decision in Strategic Partnerships" Journal of Purchasing and Materials Management, 26(4): 8-14.

Evans, R. H. (1980) "Choice Criteria Revisited" Journal of Marketing, 44(1): 55-56.

Fazlollahtabar, H., Mahdavi, I., TalebiAshoori, M., Kaviani, S., Mahdavi-Amiri, N. (2011) "A Multi-Objective Decision-Making Process of Supplier Selection and Order Allocation for Multi-Period Scheduling in An Electronic Market" International Journal of Advanced Manufacturing Technology, 52: 1039-1052.

Fontela, E. ve Gabus, A. (1974) "DEMATEL, Innovative Methods, Report no. 2, Structural Analysis of the World Problematique", Battelle Geneva Research Institute.

Fontela, E. ve Gabus, A. (1976) "The DEMATEL Observer: Battelle Institute", Geneva Research Center.

Garfamy, R.M. (2006) "A Data Envelopment Analysis Approach Based on Total Cost of Ownership for Supplier Selection" Journal of Enterprise Information Management, 19(6): 662-678.

Gencer, C. ve Gürpinar, D. (2007) "Analytic Network Process in Supplier Selection: A Case Study in an Electronic Firm" Applied Mathematical Modeling, 31(11): $2475-2486$.

Gharakhani, D. (2012) "The Evaluation of Supplier Selection Criteria by Fuzzy DEMATEL Method" Journal of Basic and Applied Scientific Research, 2(4): 3215-3224.
Ghodsypur, S. H. ve O’Brien, C. (1998) “A Decision Support System for Supplier Selection Using an Integrated Analytic Hierarchy Process and Linear Programming" International Journal of Production Economics, 56-57: 199-212.

Göktürk, İ.F., Eryılmaz, A.Y., Yörür, B. ve Yuluğkural, Y. (2011) "Bir İşletmenin Tedarikçi Değerlendirme ve Seçim Probleminin Cözümünde AAS ve VIKOR Yöntemlerinin Kullanılması" Dumlupinar Üniversitesi Fen Bilimleri Enstitüsü Dergisi, 25: 61-74.

Görener, A. (2011) "Bütünleşik ANP-VIKOR Yaklaşımı ile ERP Yazılımı Seçimi” Havacılık ve Uzay Teknolojileri Dergisi, 5(1): 97-110.

Guang, Y., Wen-Jie, H. ve Lin-Li, L. (2010) "Using AHP and TOPSIS Approaches in Nuclear Power Plant Equipment Supplier Selection" Key Engineering Materials, 419-420: 761-764.

Ho, W., Xu, X. ve Dey, P.K. (2010) "Multi-Criteria Decision Making Approaches for Supplier Evaluation and Selection: A Literature Review" European Journal of Operational Research, 202(1): 16-24.

Hou, J. ve Su, D. (2007) "EJB-MVC Oriented Supplier Selection System for Mass Customization" Journal of Manufacturing Technology Management, 18(1): 54-71.

Hsu, C-W. ve Hu, A.H. (2009) "Applying Hazardous Substance Management to Supplier Selection Using Analytic Network Process" Journal of Cleaner Production, 17(2): 255-264.

Hsu, C-W., Kuo, T-C., Chen, S-H. ve Hu, A.H. (2013) "Using DEMATEL to Develop A Carbon Management Model of Supplier Selection in Green Supply Chain Management" Journal of Cleaner Production, 56: 164-172.

Huang, S.H. ve Keska, H. (2007) "Comprehensive and Configurable Metrics for Supplier Selection" International Journal of Production Economics, 105(2): 510-523.

Jadidi, O., Firouzi, F. ve Bagliery, E. (2010) “TOPSIS Method for Supplier Selection Problem" World Academy of Science, Engineering and Technology, 47: 956-958.

Jharkharia, S. ve Shankar, R. (2007) "Selection of Logistics Service Provider: An Analytic Network Process (ANP) Approach" The International Journal of Management Science, 35: 274-289.

Jianxun, Q., Zhiguang, Z., ve Feng, K. (2007) "Selection of Suppliers Based on VIKOR Algorithm" In Control Conference, CCC 2007, Chinese IEEE: 146-148.

Kahraman, C., Cebeci, U. ve Ulukan, Z. (2003) "Multi-Criteria Supplier Selection Using Fuzzy AHP" Logistics Information Management, 16(6): 382-394.

Kermani, M.A.M.A., Malaei, A. ve Nasiri, M. (2011) "Presenting a Mathematical Programming Model for Green Supplier Selection" Proceedings of the 41st International Conference on Computers \& Industrial Engineering, 648-653.

Lee, A.H.I. (2009) "A Fuzzy Supplier Selection Model with the Consideration of Benefits, Opportunities, Costs and Risks", Expert Systems with Applications, 36(2): 2897-2893. 
Lee, A.H.I., Kang, H-Y., Hsu, C-F. ve Hung, H-C. (2009) "A Green Supplier Selection Model for High-Tech Industry" Expert Systems with Applications, 36(4): 7917-7927.

Li, G-D., Yamaguchi, D. ve Nagai, M. (2007) "A Grey-Based Decision-Making Approach to the Supplier Selection Problem" Mathematical and Computer Modelling, 46(3-4): 573-581.

Lin, M.C., Wang, C.C., Chen, M.S. ve Alec Chang, C. (2008) "Using AHP and TOPSIS Approaches in Customer-Driven Product Design Process" Computers in Industry, 59: 17-31.

Lin, C.W., Chen, S.H. ve Tzeng, G.H. (2009) "Constructing a Cognition Map of Alternative Fuel Vehicles Using the DEMATEL Method" Journal of Multi-Criteria Decision Analysis, 16: 5-19.

Liou, J., Tsai, C., Lin, R. ve Tzeng, G. (2011) "A Modified VIKOR Multiple-Criteria Decision Method for Improving Domestic Airlines Service Quality" Journal of Air Transport Management, 17: 57-61.

Liu, J. Ding, F-Y. ve Lall, V. (2000) "Using Data Envelopment Analysis to Compare Suppliers For Supplier Selection and Performance Improvement" Supply Chain Management: An International Journal, 5(3): 143-150.

Liu, F.H.F. ve Hai, H.L. (2005) "The Voting Analytic Hierarchy Process Method for Selecting Supplier" International Journal of Production Economics, 97(3): 308-317.

Mazurak, R.E., Rao, S.R. ve Scotton, D.W. (1985) "Spreadsheet Software Application in Purchasing" Journal of Purchasing and Materials Management, 21: 8-16.

Muralidharan, C., Anantharaman, N. ve Deshmukh, S.G. (2002) "A Multi-Criteria Group Decision-Making Model for Supplier Rating" Journal of Supply Chain Management, 38(4): 22-33.

Nydick, R.L. ve Hill, R.P. (1992) "Using the Analytic Hierarchy Process to Structure the Supplier Selection Procedure" International Journal of Purchasing and Materials Management; 28(2): 31-36.

Opriovic, S. ve Tzeng, G. (2004). "Compromise Solutions by MCDM Methods: A Comparative Analysis of VIKOR and TOPSIS" European Journal of Operational Research, 156:445-455

Opriovic, S. ve Tzeng, G. (2007) "Extended VIKOR Method in Comparison with Outranking Methods" European Journal of Operational Research, 178: 514-529.

Önüt, S., Kara, S.S. ve Işik, E. (2009) "Long Term Supplier Selection Using a Combined Fuzzy MCDM Approach: A Case Study for a Telecommunication Company" Expert Systems with Applications, 36(2): 3887-3895.

Öz, E. ve Baykoç, Ö.F. (2004) "Tedarikçi Seçimi Problemine Karar Teorisi Destekli Uzman Sistem Yaklaşımı" Gazi Üniversitesi Mühendislik-Mimarlık Fakültesi Dergisi, 19(3): 275-286.

Pi, W.N.ve Low, C. (2006) "Supplier Evaluation and Selection Via Taguchi Loss Functions and An AHP" International Journal of Advanced Manufacturing Technology, 27: 625-630.
Ramanathan, R. (2007) "Supplier Selection Problem: Integrating DEA with the Approaches of Total Cost Ownership and AHP" Supply Chain Management: An International Journal, 12(4): 258-261.

Raut, R.D., Bhasin, H. V. ve Kamble S.S. (2011) "Evaluation of Supplier Selection Criteria By Combination of AHP and Fuzzy DEMATEL Method" International Journal of Business Innovation and Research, 5(4): 359-392.

Saaty, T.L. ( 2000), Fundamentals of Decision Making and Priority Theory with the Analytic Hierarchy Process, Vol VI of the AHP Series, RWS Publications.

Saaty, T.L. (2009) "Applications of Analytic Network Process in Entertainment" Iranian Journal of Operations Research, 1(2): 41-55.

Saaty, T. L. ve Vargas, L. G. (2006) “Decision Making with the Analytic Network Process: Economic, Political, Social and Technological Applications with Benefits, Opportunities, Costs and Risks", Springer Science+Business Media, LLC, New York, USA.

Sanayei, A., Mousavi, S.F. ve Yazdankhah, A. (2010) "Group Decision Making Process for Supplier Selection with VIKOR Under Fuzzy Environment" Expert Systems with Applications, 37: 24-30.

Sarkis, J. ve Talluri, S. (2002) "A Model for Strategic Supplier Selection" Journal of Supply Chain Management, 38(1): 18-28.

Seçme, N. ve Özdemir, A.İ. (2008) "Bulanık Analitik Hiyerarşi Yöntemi ile Çok Kriterli Stratejik Tedarikçi Seçimi: Türkiye Örneği” Atatürk Üniversitesi IIIBF Dergisi, 22(2): 175-191.

Sevim, U., Ar, İ.M. ve Baki, B. (2011) "Yeniliği Engelleyen Finansal Faktörlerin Dematel Yöntemi ile Değerlendirilmesi” XI. Ulusal Üretim Araștrmalar Sempozyumu (ÜAS'11), 23-24 Haziran, İstanbul Ticaret Üniversitesi, İstanbul.

Sevkli, M. (2010) "An Application of the Fuzzy ELECTRE Method for Supplier Selection" International Journal of Production Research, 48(12): 3393-3405.

Sevkli, M., Koh, S.C.L., Zaim, S., Demirbag, M. ve Tatoglu, E. (2007) "An Application of Data Envelopment Analytic Hierarchy Process for Supplier Selection: A Case Study of BEKO in Turkey" International Journal of Production Research, 45(9): 1973-2003.

Sevkli, M. Koh, S.C.L., Zaim, S., Demirbag, M. ve Tatoglu, E. (2008) "Hybrid Analytical Hierarchy Process Model for Supplier Selection" Industrial Management \& Data Systems, 108(1): 122-142.

Shahroudi, K., Rouydel H., Assimi, S., ve Eyvazi, H.R. (2011) "Supplier Selection and Order Allocation A Main Factor in Supply Chain" 3rd International Conference on Advanced Management Science, IACSIT Press, Singapore.

Shahroudi, K. ve Rouydel, H. (2012) "Using A Multi-Criteria Decision Making Approach (ANPTOPSIS) to Evaluate Suppliers In Iran's Auto Industry" International Journal of Applied Operational Research, 2(2): 37-48. 
Shemshadi, A., Shiraz, H., Toreihi, M. ve Tarokh, M.J. (2011) "A Fuzzy VIKOR Method For Supplier Selection Based on Entropy Measure for Objective Weighting" Expert Systems with Applications, 38(10): 1216012167.

Shen, J-L., Liu, Y-M. ve Tzeng, Y.L. (2012) “The Cluster-Weighted DEMATEL with ANP Method for Supplier Selection in Food Industry" Journal of Advanced Computational Intelligence and Intelligent Informatics, 16(5): 567-575.

Shieh, J.I., Wu, H.H. ve Huang, K.K. (2010) "A DEMATEL Method in Identifying Key Success Factors of Hospital Service Quality" Knowledge-Based Systems, 23: 277-282.

Shipley, D.D. (1985) "Resellers Supplier Selection Criteria for Different Consumer Products" European Journal of Marketing, 19(7): 26-36.

Supçiller, A.A. ve Çapraz, O. (2011) "AHP-TOPSIS Yöntemine Dayalı Tedarikçi Seçimi Uygulaması" İstanbul Üniversitesi İktisat Fakültesi Ekonometri ve Istatistik Dergisi (12.Uluslararası Ekonometri, Yöneylem Araştırması ve İstatistik Sempozyumu Özel Sayısı), 13: 1-22.

Talluri, S. ve Sarkis, J., (2002) "A Model for Performance Monitoring of Suppliers" International Journal of Production Research, 40(16): 4257-4269.

Tayyar, N. ve Arslan, P. (2013) "Hazır Giyim Sektöründe En İyi Fason İşletme Seçimi İçin AHP ve VIKOR Yöntemlerinin Kullanılması" Celal Bayar Üniversitesi Sosyal Bilimler Dergisi, 11(1): 340-358.

Thipparat, T. ve Thaseepetch, T. (2013) "An Integrated VIKOR and Fuzzy AHP Method for Assessing a Sustainable Research Project" World Applied Sciences Journal, 22 (12): 1729-1738.

Tsai, W-H. ve Chou, W-C. (2009) "Selecting Management Systems for Sustainable Development in SMEs: A Novel Hybrid Model Based on DEMATEL, ANP and ZOGP” Expert Systems with Applications, 36: 1444-1458.

Tseng, Y-J. ve Lin, Y-H. (2005) "A Model for Supplier Selection and Tasks Assignment" Journal of American Academy of Business, 6(2): 197-207.

Tuzkaya, G., Önüt, S., Tuzkaya, U.R. ve Gülsün, B. (2008) "An Analytic Network Process Approach for Locating Undesirable Facilities: An Example from Istanbul, Turkey" Journal of Environmental Management, 88: 970983.
URL 1, http://www.dunyainsaat.com.tr/dergioku. php?haberid=3820, (Erişim Tarihi: 01.02.2015)

URL 2, http://www.iletken.org.tr/DC/File/2012kablo-sektoru.doc, (Erişim Tarihi: 19.01.2015)

Venkatraman, N. ve Ramanujam, V. (1986) “Measurement of Business Performance in Strategy Research: A Comparison of Approaches" Academy of Management Review, 11(4): 801-814.

Vimal, J., Chaturverdi, V. ve Dubey, A.K, (2012) "Application of Topsis Method for Supplier Selection in Manufacturing Industry" IJREAS, 2(5): 25-35.

Wang, J-W., Cheng, C-H. ve Huang, K.C. (2009) "Fuzzy Hierarchical TOPSIS for Supplier Selection" Applied Soft Computing, 9(1): 377-386.

Weber, C. A., Current, J.R. ve Benton, W.C. (1991) "Vendor Selection Criteria and Methods" European Journal of Operational Research, 50: 2-18.

Wu, D. (2009a) "Supplier Selection: A Hybrid Model Using DEA, Decision Tree and Neural Network" Expert Systems with Applications, 36(5): 9105-9112.

Wu, D. (2009b) "Supplier Selection in a Fuzzy Group Setting: A Method Using Grey Related Analysis and Dempster-Shafer Theory" Expert Systems with Applications, 36(5): 8892-8899.

Xia, W. ve Wu, Z. (2007) "Supplier Selection with Multiple Criteria in Volume Discount Environments" Omega, 35(5): 494-504.

Yang, C-C. ve Chen, B-S. (2006) "Supplier Selection Using Combined Analytical Hierarchy Process and Grey Relational Analysis" Journal of Manufacturing Technology Management, 17(7): 926-941.

Yahya, S. ve Kingsman, B. (1999) "Vendor Rating for An Entrepreneur Development Programme: A Case Study Using the Analytic Hierarchy Process Method" Journal of the Operational Research Society, 50: 916-930.

Yılmaz, E. (2012) "Bulanık AHP-VIKOR Bütünleşik Yöntemi ile Tedarikçi Seçimi” Marmama Üniversitesi İIBF Dergisi, 33(2): 331-354.

Yurdakul, M. ve İç Y.T. (2001) “AHP ve Hedef Programlama Yöntemlerinin Sağlayıcı Seçimi Probleminde Kullanılması", XXII. Ulusal YA/EM Kongresi, Gazi Üniversitesi, Ankara, 2001.

Zviran, M.A. (1993) "Comprehensive Methodology for Computer Family Selection" Journal Systems Software, 22: $17-26$ 


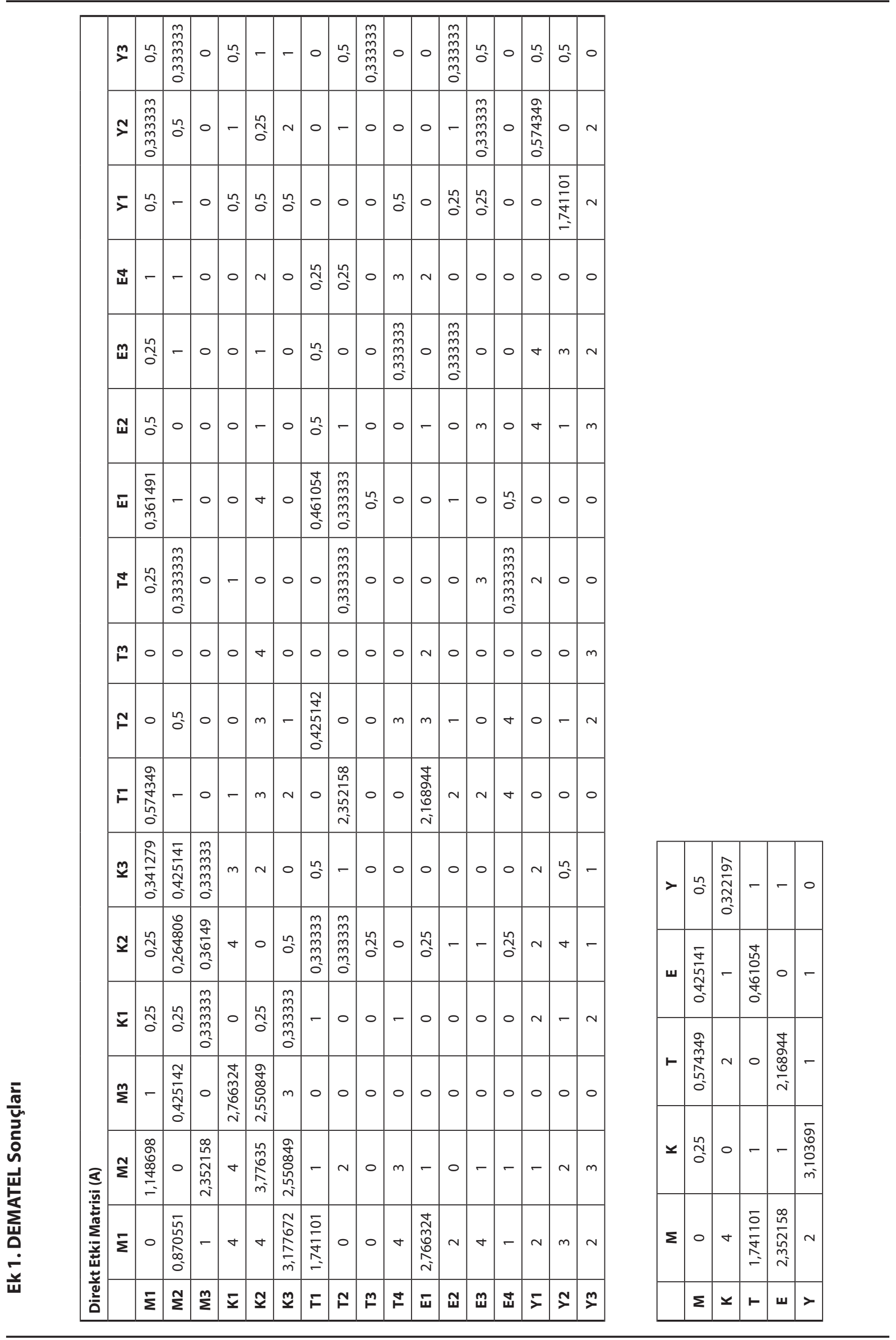




\begin{tabular}{|c|c|c|c|c|c|c|c|c|c|c|c|c|c|c|c|c|c|c|}
\hline & $\stackrel{m}{>}$ & 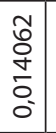 & $\begin{array}{l}n \\
\hat{n} \\
\hat{o} \\
0 \\
0\end{array}$ & 0 & $\begin{array}{l}0 \\
0 \\
\vdots \\
\vdots \\
0 \\
0\end{array}$ & $\begin{array}{l}\tilde{n} \\
\stackrel{0}{0} \\
\tilde{O} \\
0 \\
0\end{array}$ & 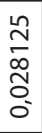 & 0 & $\begin{array}{l}0 \\
0 \\
o \\
0 \\
0 \\
0\end{array}$ & \begin{tabular}{|l|l} 
\\
$\hat{\alpha}$ \\
$\hat{o}$ \\
0 \\
0 \\
0
\end{tabular} & 0 & 0 & \begin{tabular}{|l} 
n \\
$\hat{\alpha}$ \\
Oे \\
0 \\
0
\end{tabular} & \begin{tabular}{|l}
0 \\
0 \\
$o$ \\
$\vdots$ \\
0 \\
0 \\
0
\end{tabular} & 0 & 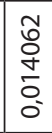 & 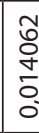 & 0 \\
\hline & 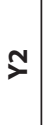 & $\begin{array}{l}n \\
\hat{n} \\
0 \\
0 \\
0\end{array}$ & $\begin{array}{l}0 \\
0 \\
0 \\
0 \\
0 \\
0\end{array}$ & 0 & $\begin{array}{l}\mathfrak{n} \\
\stackrel{n}{\infty} \\
\tilde{D} \\
0 \\
0\end{array}$ & $\mid \begin{array}{l}\bar{m} \\
\hat{\rho} \\
0 \\
0 \\
0\end{array}$ & 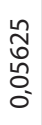 & 0 & $\begin{array}{l}n \\
0 \\
\infty \\
0 \\
0 \\
0\end{array}$ & 0 & 0 & 0 & \begin{tabular}{|l}
$n$ \\
$\tilde{N}$ \\
$o$ \\
0 \\
0 \\
0 \\
0
\end{tabular} & \begin{tabular}{|l|}
$n$ \\
$\hat{m}$ \\
$\hat{o}$ \\
$o$ \\
0 \\
0
\end{tabular} & 0 & \begin{tabular}{|l}
$\mathbf{H}$ \\
$\mathbf{L}$ \\
0 \\
0 \\
0 \\
0
\end{tabular} & 0 & 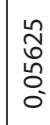 \\
\hline & $\overline{>}$ & $\begin{array}{l}\text { o } \\
⿱ 亠 \\
\vdots \\
0 \\
0\end{array}$ & 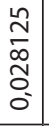 & 0 & 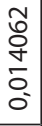 & $\left|\begin{array}{l}1 \\
0 \\
o \\
\vdots \\
0 \\
0\end{array}\right|$ & 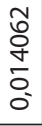 & 0 & 0 & 0 & 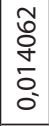 & 0 & $\begin{array}{l}\bar{m} \\
\hat{0} \\
0 \\
0 \\
0\end{array}$ & $\mid \begin{array}{l}\bar{m} \\
0 \\
0 \\
0 \\
0\end{array}$ & 0 & 0 & 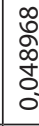 & 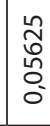 \\
\hline & $\dot{\Psi}$ & $\begin{array}{l}\underset{n}{0} \\
\underset{\infty}{0} \\
\widetilde{0} \\
0 \\
0\end{array}$ & 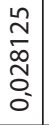 & 0 & 0 & $\mid \begin{array}{l}\hat{2} \\
0 \\
น \\
0 \\
0 \\
0\end{array}$ & 0 & $\begin{array}{l}\bar{m} \\
0 \\
o \\
0 \\
0\end{array}$ & $\begin{array}{l}\overline{\tilde{n}} \\
\hat{0} \\
0 \\
0\end{array}$ & 0 & $\begin{array}{l}n \\
\hat{m} \\
0 \\
0 \\
0 \\
0\end{array}$ & $\begin{array}{l}0 \\
0 \\
0 \\
0 \\
0 \\
0\end{array}$ & 0 & 0 & 0 & 0 & 0 & 0 \\
\hline & $\boldsymbol{m}$ & $\begin{array}{l}\bar{m} \\
\hat{0} \\
0 \\
0 \\
0\end{array}$ & 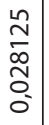 & 0 & 0 & 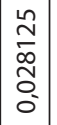 & 0 & $\left|\begin{array}{c}0 \\
o \\
o \\
0 \\
0 \\
0\end{array}\right|$ & 0 & 0 & $\begin{array}{l}\text { ñ } \\
\hat{n} \\
o \\
o \\
0 \\
0\end{array}$ & 0 & \begin{tabular}{|l} 
n \\
$\hat{n}$ \\
$o \hat{o}$ \\
$o$ \\
0
\end{tabular} & 0 & 0 & 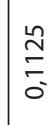 & $\begin{array}{l}\stackrel{1}{n} \\
0 \\
0 \\
0 \\
0\end{array}$ & 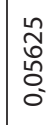 \\
\hline & $\boldsymbol{\Psi}$ & $\begin{array}{l}\tilde{o} \\
+ \\
\vdots \\
0 \\
0\end{array}$ & 0 & 0 & 0 & $\mid \begin{array}{c}\tilde{N} \\
\stackrel{\infty}{0} \\
\tilde{0} \\
0 \\
0\end{array}$ & 0 & $\mid \begin{array}{c}0 \\
o \\
o \\
0 \\
0 \\
0\end{array}$ & 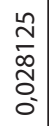 & 0 & 0 & 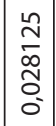 & 0 & $\mid \begin{array}{l}n \\
\hat{m} \\
\hat{q} \\
o \\
0 \\
0\end{array}$ & 0 & $\frac{\stackrel{n}{N}}{\underline{c}}$ & 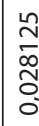 & $\begin{array}{l}n \\
\tilde{n} \\
\tilde{y} \\
o \\
0 \\
0\end{array}$ \\
\hline & $\overline{\boldsymbol{u}}$ & $\begin{array}{l}0 \\
0 \\
0 \\
0 \\
0\end{array}$ & $\begin{array}{l}\stackrel{\sim}{\sim} \\
\stackrel{\infty}{0} \\
\tilde{0} \\
0\end{array}$ & 0 & 0 & 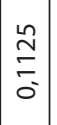 & 0 & 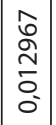 & $\begin{array}{l}\hat{n} \\
\hat{n} \\
o \\
0 \\
0\end{array}$ & $\mid \begin{array}{l}0 \\
o \\
o \\
0 \\
0 \\
0\end{array}$ & 0 & 0 & $\mid \begin{array}{l}\tilde{N} \\
\tilde{\sigma} \\
\tilde{D} \\
0 \\
0\end{array}$ & 0 & 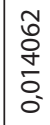 & 0 & 0 & 0 \\
\hline & $\mathbb{F}$ & 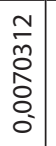 & $\begin{array}{l}n \\
\hat{N} \\
\hat{m} \\
\stackrel{0}{0} \\
0\end{array}$ & 0 & 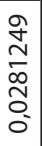 & 0 & 0 & 0 & $\begin{array}{l}\text { no } \\
\hat{m} \\
o \\
o \\
0\end{array}$ & 0 & 0 & 0 & 0 & 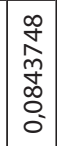 & $\begin{array}{l}n \\
\text { no } \\
\text { ng } \\
\delta \\
0 \\
0\end{array}$ & 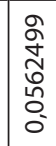 & 0 & 0 \\
\hline & 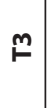 & 0 & 0 & 0 & 0 & $\stackrel{\stackrel{n}{ٍ}}{\underset{\sigma}{0}}$ & 0 & 0 & 0 & 0 & 0 & 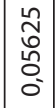 & 0 & 0 & 0 & 0 & 0 & $\begin{array}{l}\text { n } \\
\tilde{m} \\
\tilde{o} \\
0 \\
0\end{array}$ \\
\hline & $\mathfrak{F}$ & 0 & 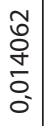 & 0 & 0 & $\mid \begin{array}{l}n \\
\hat{n} \\
\tilde{0} \\
0 \\
0 \\
0\end{array}$ & 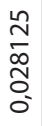 & $\mid \begin{array}{l}\hat{n} \\
\hat{\sigma} \\
0 \\
0\end{array}$ & 0 & 0 & \begin{tabular}{|l}
$n$ \\
$\hat{m}$ \\
$\tilde{o}$ \\
0 \\
0 \\
0
\end{tabular} & $\begin{array}{l}n \\
\hat{m} \\
0 \\
0 \\
0 \\
0\end{array}$ & $\mid \begin{array}{l}\tilde{n} \\
\tilde{N} \\
\tilde{D} \\
\tilde{0} \\
0\end{array}$ & 0 & 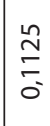 & 0 & 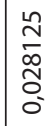 & $\begin{array}{l}\text { బ. } \\
0 \\
0 \\
0 \\
0 \\
0\end{array}$ \\
\hline & $F$ & $\begin{array}{l}\frac{1}{2} \\
\frac{n}{6} \\
0 \\
0 \\
0\end{array}$ & 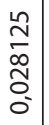 & 0 & $\begin{array}{l}\tilde{n} \\
\stackrel{D}{\infty} \\
\tilde{D} \\
0 \\
0\end{array}$ & $\mid \begin{array}{l}n \\
\hat{n} \\
\tilde{\alpha} \\
0 \\
0 \\
0\end{array}$ & 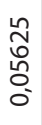 & 0 & $\begin{array}{l}1 \\
n \\
0 \\
o \\
0 \\
0\end{array}$ & 0 & 0 & $\begin{array}{l}\bar{\delta} \\
\bar{o} \\
0 \\
0\end{array}$ & 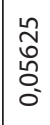 & $\mid \begin{array}{l}\tilde{L} \\
0 \\
0 \\
0 \\
0\end{array}$ & $\frac{\stackrel{2}{N}}{\sigma}$ & 0 & 0 & 0 \\
\hline & $\underline{\tilde{m}}$ & $\begin{array}{l}\infty \\
\vdots \\
\alpha \\
0 \\
0 \\
0\end{array}$ & $\begin{array}{l}\hat{n} \\
\alpha \\
\vdots \\
0 \\
0\end{array}$ & $\begin{array}{l}n \\
\hat{n} \\
o \\
o \\
0 \\
0\end{array}$ & $\begin{array}{l}n \\
\hat{m} \\
0 \\
o \\
0 \\
0\end{array}$ & $\mid \begin{array}{l}\tilde{\imath} \\
0 \\
\stackrel{\leftrightarrow}{0} \\
0\end{array}$ & 0 & $\mid \begin{array}{c}0 \\
0 \\
o \\
\vdots \\
0 \\
0\end{array}$ & $\begin{array}{l}0 \\
0 \\
\infty \\
0 \\
0 \\
0\end{array}$ & 0 & 0 & 0 & 0 & 0 & 0 & $\mid \begin{array}{l}n \\
\tilde{O} \\
0 \\
0 \\
0 \\
0\end{array}$ & $\begin{array}{l}0 \\
o \\
o \\
o \\
o \\
0\end{array}$ & 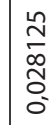 \\
\hline & $\underline{\mathscr{x}}$ & $\begin{array}{l}\bar{m} \\
\hat{0} \\
0 \\
0 \\
0\end{array}$ & 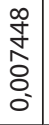 & $\mid \begin{array}{l}0 \\
0 \\
0 \\
0 \\
0\end{array}$ & 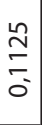 & 0 & 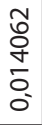 & $\begin{array}{l}n \\
\hat{N} \\
o \\
o \\
0\end{array}$ & $\begin{array}{l}n \\
\hat{o} \\
o \\
o \\
0 \\
0\end{array}$ & $\mid \begin{array}{l}\bar{n} \\
0 \\
o \\
0 \\
0\end{array}$ & 0 & $\begin{array}{l}\bar{m} \\
\hat{0} \\
0 \\
0 \\
0\end{array}$ & \begin{tabular}{|l}
$\tilde{N}$ \\
$\tilde{\alpha}$ \\
$\tilde{D}$ \\
0 \\
0
\end{tabular} & $\mid \begin{array}{l}\tilde{N} \\
\tilde{o} \\
\tilde{0} \\
\tilde{0} \\
0\end{array}$ & $\begin{array}{l}\bar{m} \\
0 \\
0 \\
0 \\
0\end{array}$ & 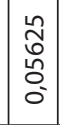 & 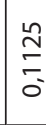 & $\begin{array}{l}\tilde{N} \\
\sim \\
0 \\
\tilde{D} \\
0 \\
0\end{array}$ \\
\hline & $\bar{x}$ & $\begin{array}{l}\bar{m} \\
\hat{o} \\
0 \\
0 \\
0\end{array}$ & $\begin{array}{l}\bar{m} \\
\hat{0} \\
0 \\
0 \\
0\end{array}$ & $\begin{array}{l}0 \\
\hat{n} \\
o \\
o \\
0 \\
0\end{array}$ & 0 & $\begin{array}{l}\overline{\tilde{n}} \\
\hat{0} \\
0 \\
0 \\
0\end{array}$ & 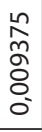 & $\begin{array}{l}0 \\
\tilde{0} \\
\infty \\
\tilde{0} \\
0 \\
0\end{array}$ & 0 & 0 & $\begin{array}{l}\stackrel{n}{0} \\
\stackrel{0}{o} \\
\tilde{0} \\
0 \\
0\end{array}$ & 0 & 0 & 0 & 0 & $\begin{array}{l}n \\
\tilde{\sigma} \\
0 \\
0 \\
0 \\
0\end{array}$ & 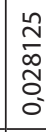 & $\begin{array}{l}\text { బ. } \\
\text { on } \\
0 \\
0 \\
0\end{array}$ \\
\hline 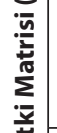 & $\sum^{m}$ & 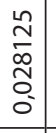 & $\begin{array}{l}\hat{n} \\
\sigma \\
\overline{0} \\
0\end{array}$ & 0 & $\begin{array}{l}m \\
0 \\
0 \\
\hat{0} \\
0 \\
0\end{array}$ & $\begin{array}{c}\tilde{N} \\
\hat{N} \\
0 \\
0\end{array}$ & $\begin{array}{l}n \\
\tilde{n} \\
\text { d } \\
0 \\
0 \\
0\end{array}$ & 0 & 0 & 0 & 0 & 0 & 0 & 0 & 0 & 0 & 0 & 0 \\
\hline 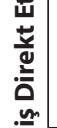 & $\tilde{\Sigma}$ & $\begin{array}{l}\hat{\tilde{ల}} \\
\tilde{\widetilde{N}} \\
0 \\
0\end{array}$ & 0 & 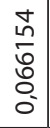 & $\frac{\stackrel{n}{N}}{\bar{\sigma}}$ & $\mid \begin{array}{c}\overline{\widehat{\sigma}} \\
\frac{0}{0} \\
\end{array}$ & 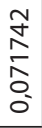 & \begin{tabular}{|c}
$n$ \\
0 \\
$\infty$ \\
0 \\
0 \\
0 \\
\end{tabular} & 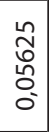 & 0 & \begin{tabular}{|l} 
n \\
$\hat{m}$ \\
o \\
0 \\
0 \\
\end{tabular} & $\begin{array}{l}\mathfrak{n} \\
0 \\
0 \\
0 \\
0 \\
0\end{array}$ & 0 & $\begin{array}{l}n \\
\tilde{N} \\
0 \\
\tilde{0} \\
0 \\
0\end{array}$ & \begin{tabular}{|l}
$\tilde{N}$ \\
$\tilde{N}$ \\
$\tilde{D}$ \\
0 \\
0 \\
0
\end{tabular} & $\begin{array}{l}n \\
\tilde{N} \\
0 \\
\tilde{0} \\
0 \\
0\end{array}$ & $\begin{array}{l}\text { م̂ } \\
\text { L } \\
0 \\
0\end{array}$ & $\begin{array}{l}n \\
\hat{n} \\
\hat{y} \\
0 \\
0 \\
0\end{array}$ \\
\hline 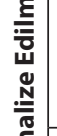 & $\bar{\Sigma}$ & 0 & 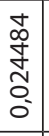 & 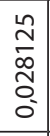 & $\begin{array}{l}\stackrel{n}{N} \\
\overline{0} \\
\end{array}$ & 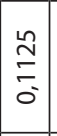 & $\begin{array}{l}\text { No } \\
\text { Oू } \\
o \\
o \\
0 \\
\end{array}$ & \begin{tabular}{|l|} 
\\
0 \\
$o$ \\
$\infty$ \\
0 \\
0 \\
0 \\
\end{tabular} & 0 & 0 & $\frac{\stackrel{n}{\mathfrak{n}}}{\tilde{\sigma}}$ & $\begin{array}{l}m \\
0 \\
0 \\
0 \\
0 \\
0 \\
0\end{array}$ & 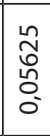 & $\begin{array}{l}\stackrel{n}{\simeq} \\
\check{\sigma} \\
\end{array}$ & 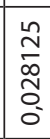 & $\begin{array}{l}n \\
0 \\
0 \\
2 \\
0 \\
0 \\
0\end{array}$ & $\begin{array}{l}\hat{n} \\
\hat{\jmath} \\
\infty \\
0 \\
0\end{array}$ & 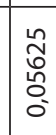 \\
\hline $\begin{array}{l}\text { c } \\
\text { o }\end{array}$ & & $\bar{\Sigma}$ & 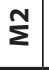 & $\sum^{m}$ & $\mathbf{x}$ & $\mathbf{\widetilde { x }}$ & 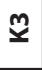 & $F$ & $r$ & $\boldsymbol{m}$ & $\vdash$ & $\overline{\mathbf{u}}$ & 山 & $\boldsymbol{m}$ & & & 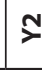 & \\
\hline
\end{tabular}

\begin{tabular}{|c|c|c|c|c|c|}
\hline$>$ & $\mid \begin{array}{l}\infty \\
0 \\
\tilde{N} \\
\hat{\alpha} \\
0 \\
0 \\
0\end{array}$ & $\mid \begin{array}{l}\tilde{z} \\
\tilde{\tilde{m}} \\
\tilde{\tilde{o}} \\
0\end{array}$ & $\begin{array}{l}0 \\
0 \\
0 \\
0 \\
0 \\
0\end{array}$ & $\begin{array}{l}0 \\
0 \\
0 \\
0 \\
0 \\
0\end{array}$ & 0 \\
\hline w & 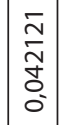 & \begin{tabular}{|l|}
0 \\
0 \\
0 \\
0 \\
0 \\
0 \\
0
\end{tabular} & $\begin{array}{l}\hat{0} \\
0 \\
\vdots \\
0 \\
0 \\
0\end{array}$ & 0 & $\begin{array}{l}0 \\
0 \\
0 \\
0 \\
0 \\
0 \\
0\end{array}$ \\
\hline$\vdash$ & $\left|\begin{array}{l}0 \\
0 \\
0 \\
0 \\
0 \\
0 \\
0\end{array}\right|$ & 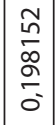 & 0 & 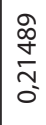 & 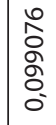 \\
\hline 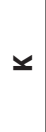 & 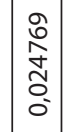 & 0 & $\begin{array}{l}0 \\
0 \\
0 \\
0 \\
0 \\
0\end{array}$ & $\begin{array}{l}0 \\
0 \\
0 \\
0 \\
0 \\
0\end{array}$ & 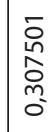 \\
\hline$\Sigma$ & 0 & 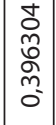 & 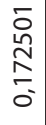 & $\begin{array}{l}\mathcal{N} \\
\tilde{m} \\
\tilde{N} \\
\delta\end{array}$ & 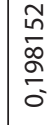 \\
\hline & $\Sigma$ & & & 山 & \\
\hline
\end{tabular}




\begin{tabular}{|c|c|c|c|c|c|c|c|c|c|c|c|c|c|c|c|c|c|c|}
\hline & $\stackrel{m}{x}$ & $\left|\begin{array}{l}0 \\
0 \\
0 \\
0\end{array}\right|$ & $\stackrel{\bar{m}}{\bar{m}}_{0}$ & $\widetilde{\widetilde{\sigma}}$ & 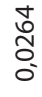 & $\begin{array}{l}\text { o. } \\
0 \\
0\end{array}$ & 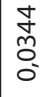 & $\mid \begin{array}{l}0 \\
0 \\
0 \\
0 \\
0\end{array}$ & 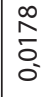 & $\mid$\begin{tabular}{|l}
$\infty$ \\
0 \\
0 \\
0 \\
0
\end{tabular} & $\mid \begin{array}{l}\overline{0} \\
0 \\
0\end{array}$ & $\begin{array}{l}\text { co } \\
\stackrel{0}{0} \\
0 \\
0\end{array}$ & $\mid \begin{array}{l}n \\
\tilde{m} \\
0 \\
0\end{array}$ & 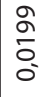 & $\mid \begin{array}{l}0 \\
0 \\
0 \\
0 \\
0\end{array}$ & $\mid \begin{array}{l}\hat{\hat{n}} \\
0 \\
0\end{array}$ & 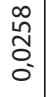 & 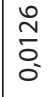 \\
\hline & N & $\mid \begin{array}{c}0 \\
m \\
0 \\
0 \\
0\end{array}$ & $\begin{array}{l}\stackrel{\infty}{\infty} \\
\stackrel{0}{0}\end{array}$ & ๙ેे & 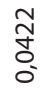 & 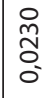 & 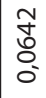 & $\begin{array}{l}\hat{y} \\
0 \\
0 \\
0\end{array}$ & 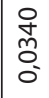 & $\mid \begin{array}{l}0 \\
\grave{o} \\
0\end{array}$ & $\left|\begin{array}{l}m \\
0 \\
0 \\
0 \\
0\end{array}\right|$ & $\begin{array}{l}\text { ơ } \\
\stackrel{0}{\circ}\end{array}$ & 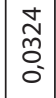 & $\mid \begin{array}{l}1 \\
\vdots \\
0 \\
0\end{array}$ & $\mid \begin{array}{l}0 \\
\text { L } \\
0 \\
0\end{array}$ & $\left|\begin{array}{l}0 \\
\tilde{n} \\
0 \\
0 \\
0\end{array}\right|$ & 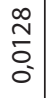 & $\begin{array}{l}0 \\
\frac{0}{0} \\
0 \\
0\end{array}$ \\
\hline & $\bar{\nearrow}$ & $\left|\begin{array}{l}\infty \\
\infty \\
0 \\
0\end{array}\right|$ & $\begin{array}{l}\text { Ñ } \\
\tilde{o} \\
0 \\
0\end{array}$ & \begin{tabular}{l}
\multirow{2}{*}{} \\
0 \\
0
\end{tabular} & 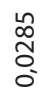 & 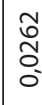 & 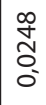 & $\begin{array}{l}\hat{m} \\
\tilde{O} \\
0\end{array}$ & $\begin{array}{l}\text { ò } \\
\text { ठ } \\
0\end{array}$ & $\begin{array}{l}0 \\
\dot{o} \\
0 \\
0\end{array}$ & 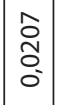 & 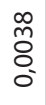 & $\frac{\infty}{\sigma}$ & $\begin{array}{l}n \\
\stackrel{n}{n} \\
0 \\
0\end{array}$ & $\mid \begin{array}{l}0 \\
\tilde{\check{c}} \\
0 \\
0\end{array}$ & 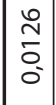 & $\begin{array}{l}\text { o } \\
0 \\
0 \\
0\end{array}$ & 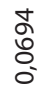 \\
\hline & 吉 & $\left|\begin{array}{l}0 \\
\tilde{m} \\
0 \\
0 \\
0\end{array}\right|$ & 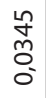 & $\begin{array}{l}m \\
\text { gे } \\
0 \\
0\end{array}$ & 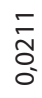 & $\begin{array}{l}\infty \\
\stackrel{\infty}{0} \\
0 \\
0\end{array}$ & $\begin{array}{l}\circ \\
\circ \\
0 \\
0\end{array}$ & 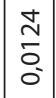 & $\begin{array}{l}\tilde{m} \\
\tilde{O} \\
0\end{array}$ & $\mid \begin{array}{l}n \\
\bar{o} \\
0 \\
0\end{array}$ & $\mid \begin{array}{l}\hat{0} \\
\hat{0} \\
0 \\
0\end{array}$ & $\begin{array}{l}\text { त్రి } \\
\text { : }\end{array}$ & $\begin{array}{l}\hat{a} \\
0 \\
0 \\
0\end{array}$ & $\mid \begin{array}{l}\tilde{b} \\
0 \\
0 \\
0\end{array}$ & $\left|\begin{array}{l}- \\
\hat{0} \\
0 \\
0\end{array}\right|$ & $\left|\begin{array}{l}N \\
\hat{L} \\
0 \\
0\end{array}\right|$ & $\begin{array}{l}0 \\
\stackrel{0}{0} \\
0 \\
0\end{array}$ & 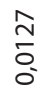 \\
\hline & m & $\left|\begin{array}{c}0 \\
m \\
0 \\
0 \\
0\end{array}\right|$ & $\begin{array}{l}\text { ô } \\
\text { Oֶ. } \\
\text { O. }\end{array}$ & $\begin{array}{l}\tilde{n} \\
\tilde{O} \\
0 \\
0\end{array}$ & $\begin{array}{l}\infty \\
\infty \\
0 \\
0\end{array}$ & $\begin{array}{l}\tilde{y} \\
\text { ơ } \\
0\end{array}$ & 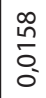 & $\mid \begin{array}{l}n \\
\hat{\sigma} \\
0 \\
0\end{array}$ & \begin{tabular}{|l}
$\infty$ \\
0 \\
0 \\
0 \\
0
\end{tabular} & $\begin{array}{l}\bar{\sigma} \\
\bar{o} \\
0\end{array}$ & $\left|\begin{array}{l}n \\
\hat{0} \\
0 \\
0\end{array}\right|$ & $\begin{array}{l}0 \\
\text { On } \\
\text { O. }\end{array}$ & $\mid \begin{array}{l}n \\
\hat{o} \\
0 \\
0\end{array}$ & : & 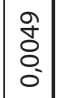 & 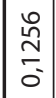 & $\begin{array}{l}\overline{\mathbf{\sigma}} \\
\stackrel{0}{0}\end{array}$ & $\begin{array}{l}0 \\
0 \\
0 \\
0 \\
0\end{array}$ \\
\hline & บิ & 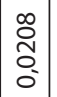 & $\frac{\bar{z}}{\bar{\delta}}$ & $\bar{\delta}$ & $\begin{array}{l}0 \\
0 \\
0 \\
0\end{array}$ & \begin{tabular}{|l}
$\overline{0}$ \\
ho \\
0
\end{tabular} & $\begin{array}{l}\hat{n} \\
\vdots \\
\vdots \\
0\end{array}$ & $\mid \begin{array}{l}0 \\
0 \\
0 \\
0 \\
0\end{array}$ & $\begin{array}{l}\text { f } \\
\tilde{O} \\
0 \\
0\end{array}$ & $\mid \begin{array}{l}0 \\
\bar{\sigma} \\
0\end{array}$ & $\mid \begin{array}{l}\overline{0} \\
0 \\
0 \\
0\end{array}$ & 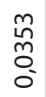 & $\begin{array}{l}8 \\
0 \\
0 \\
0\end{array}$ & $\begin{array}{l}\mathcal{Z} \\
\text { Oे } \\
0\end{array}$ & $\left|\begin{array}{l}\hat{2} \\
\hat{0} \\
0 \\
0\end{array}\right|$ & $\mid \begin{array}{l}\tilde{m} \\
m \\
0\end{array}$ & $\begin{array}{l}\bar{y} \\
\text { d. } \\
0\end{array}$ & $\begin{array}{l}\infty \\
\frac{0}{0} \\
\end{array}$ \\
\hline & $\overline{-}$ & $\left|\begin{array}{l}f \\
0 \\
0 \\
0\end{array}\right|$ & $\begin{array}{l}\stackrel{0}{0} \\
\tilde{O} \\
0 \\
0\end{array}$ & \begin{tabular}{l}
$\mathcal{1}$ \\
\multirow{0}{0}{} \\
0
\end{tabular} & 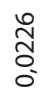 & 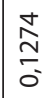 & 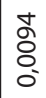 & $\begin{array}{l}1 \\
\hat{0} \\
0 \\
0\end{array}$ & $\begin{array}{l}0 \\
0 \\
0 \\
0\end{array}$ & $\mid \begin{array}{l}\tilde{n} \\
0 \\
0 \\
0\end{array}$ & $\mid \begin{array}{l}\mid c \\
0 \\
0 \\
0 \\
0\end{array}$ & $\begin{array}{l}\text { ¿ } \\
\stackrel{0}{0} \\
0\end{array}$ & $\begin{array}{l}\tilde{N} \\
\tilde{n} \\
0 \\
0\end{array}$ & $\frac{\pi}{\frac{\pi}{0}}$ & $\mid \begin{array}{l}m \\
0 \\
0 \\
0\end{array}$ & $\left|\begin{array}{l}R \\
0 \\
0 \\
0\end{array}\right|$ & $\begin{array}{l}0 \\
\stackrel{0}{v} \\
0 \\
0\end{array}$ & $\begin{array}{l}0 \\
0 \\
0 \\
0\end{array}$ \\
\hline & $\stackrel{I}{r}$ & $\mid \begin{array}{l}n \\
0 \\
0 \\
0 \\
0\end{array}$ & $\begin{array}{l}\frac{n}{n} \\
\vdots \\
0\end{array}$ & $\stackrel{\infty}{8}$ & 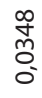 & $\frac{8}{\circ}$ & $\begin{array}{l}n \\
\text { 息 } \\
0\end{array}$ & $\mid \begin{array}{l}\hat{m} \\
\hat{o} \\
0\end{array}$ & 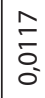 & $\mid \begin{array}{l}m \\
0 \\
0 \\
0\end{array}$ & $\left|\begin{array}{l}n \\
\hat{o} \\
0 \\
0\end{array}\right|$ & $\begin{array}{l}\text { mo } \\
\text { on } \\
0\end{array}$ & $\begin{array}{l}\tilde{o} \\
\tilde{o} \\
0 \\
0\end{array}$ & $\begin{array}{l}\text { o } \\
0 \\
0 \\
0 \\
0\end{array}$ & 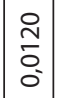 & $\left|\begin{array}{l}m \\
\hat{L} \\
0 \\
0\end{array}\right|$ & $\begin{array}{l}n \\
\stackrel{n}{n} \\
0 \\
0\end{array}$ & $\begin{array}{l}\bar{n} \\
\vdots \\
0 \\
0\end{array}$ \\
\hline & $\stackrel{m}{n}$ & $\left|\begin{array}{l}\infty \\
0 \\
0 \\
0 \\
0\end{array}\right|$ & 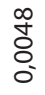 & $\frac{a}{\tilde{o}}$ & $\begin{array}{l}2 \\
\hat{0} \\
0 \\
0\end{array}$ & $\frac{\bar{n}}{\stackrel{2}{0}}$ & 秴 & $\mid \begin{array}{l}\bar{m} \\
\text { o. } \\
0\end{array}$ & 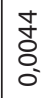 & $\mid \begin{array}{l}0 \\
\tilde{\Xi} \\
0 \\
0\end{array}$ & $\mid \begin{array}{l}\tilde{z} \\
0 \\
0 \\
0\end{array}$ & $\begin{array}{l}\stackrel{0}{0} \\
\stackrel{0}{0} \\
0 \\
0\end{array}$ & $\mid \begin{array}{l}\tilde{z} \\
\mathbf{0} \\
0 \\
0\end{array}$ & $\begin{array}{l}0 \\
0 \\
0 \\
0 \\
0\end{array}$ & $\mid \begin{array}{l}0 \\
\widetilde{0} \\
0 \\
0\end{array}$ & $\mid \begin{array}{l}\bar{z} \\
\vdots \\
0 \\
0\end{array}$ & $\begin{array}{l}0 \\
\infty \\
\vdots \\
0\end{array}$ & $\begin{array}{l}\text { శ్ } \\
\text { ठ̀ } \\
\text {. }\end{array}$ \\
\hline & $\mathfrak{F}$ & $\left|\begin{array}{l}0 \\
0 \\
0 \\
0 \\
0\end{array}\right|$ & 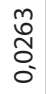 & $\mid \begin{array}{l}\infty \\
0 \\
0 \\
0 \\
0\end{array}$ & 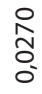 & $\frac{\hat{n}}{\stackrel{2}{0}}$ & $\begin{array}{l}\infty \\
0 \\
0 \\
0 \\
0\end{array}$ & $\mid \begin{array}{l}0 \\
0 \\
0 \\
0 \\
0\end{array}$ & $\bar{z}$ & $\mid \begin{array}{l}0 \\
\tilde{\Xi} \\
0 \\
0\end{array}$ & $\frac{\bar{o}}{\bar{o}}$ & $\begin{array}{l}\infty \\
0 \\
0 \\
0 \\
0\end{array}$ & $\begin{array}{l}n \\
\infty \\
0 \\
0 \\
0\end{array}$ & $\begin{array}{l}2 \\
\frac{8}{0} \\
\vdots \\
0\end{array}$ & $\mid$\begin{tabular}{c}
8 \\
0 \\
\hdashline \\
0
\end{tabular} & $\mid \begin{array}{l}0 \\
\vdots \\
0 \\
0 \\
0\end{array}$ & $\begin{array}{l}\tilde{O} \\
\text { Oे } \\
0\end{array}$ & $\begin{array}{l}\text { J } \\
0 \\
0\end{array}$ \\
\hline & $F$ & $\left|\begin{array}{l}1 \\
\hat{O} \\
0 \\
0\end{array}\right|$ & 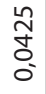 & $\begin{array}{l}\bar{q} \\
\stackrel{0}{\circ}\end{array}$ & 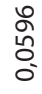 & $\mid \begin{array}{l}n \\
\stackrel{0}{0} \\
0 \\
0\end{array}$ & $\begin{array}{l}\hat{2} \\
0 \\
0 \\
0\end{array}$ & $\mid \begin{array}{l}m \\
\bar{\sigma} \\
0\end{array}$ & $\begin{array}{l}\hat{A} \\
\text { O. } \\
0\end{array}$ & $\mid \begin{array}{l}n \\
\tilde{\delta} \\
0 \\
0\end{array}$ & $\left|\begin{array}{l}0 \\
0 \\
0 \\
0 \\
0\end{array}\right|$ & $\begin{array}{l}0 \\
\stackrel{0}{0} \\
0 \\
0\end{array}$ & $\begin{array}{l}1 \\
0 \\
0 \\
0 \\
0\end{array}$ & $\mid \begin{array}{l}\infty \\
\tilde{N} \\
0 \\
0\end{array}$ & $\left|\begin{array}{l}0 \\
\stackrel{0}{0} \\
\hdashline \\
0\end{array}\right|$ & $\mid \begin{array}{l}\hat{n} \\
\hat{n} \\
0 \\
0\end{array}$ & $\begin{array}{l}\bar{q} \\
0 \\
0 \\
0\end{array}$ & $\begin{array}{l}\stackrel{\sim}{2} \\
\tilde{N} \\
0 \\
0\end{array}$ \\
\hline & $\underline{\underline{m}}$ & $\left|\begin{array}{l}\hat{f} \\
0 \\
0 \\
0\end{array}\right|$ & $\begin{array}{l}\stackrel{n}{\infty} \\
0 \\
0 \\
0\end{array}$ & $\stackrel{\infty}{\sim}$ & $\stackrel{\circ}{0}$ & \begin{tabular}{l}
0 \\
\multirow{2}{0}{} \\
0 \\
0
\end{tabular} & $\frac{\sigma}{\sigma}$ & $\left|\begin{array}{l}\infty \\
0 \\
0 \\
0 \\
0\end{array}\right|$ & $\begin{array}{l}\tilde{n} \\
\tilde{m} \\
0 \\
0\end{array}$ & $\mid \begin{array}{l}0 \\
\overline{0} \\
0 \\
0\end{array}$ & $\mid \begin{array}{l}0 \\
0 \\
0 \\
0\end{array}$ & $\begin{array}{l}0 \\
\stackrel{0}{0} \\
0 \\
0\end{array}$ & $\begin{array}{l}0 \\
0 \\
0 \\
0\end{array}$ & $\begin{array}{l}m \\
0 \\
0 \\
0 \\
0\end{array}$ & $\mid \begin{array}{l}0 \\
0 \\
0 \\
0\end{array}$ & $\mid \begin{array}{l}n \\
0 \\
0 \\
0 \\
0\end{array}$ & $\begin{array}{l}\stackrel{y}{m} \\
0 \\
0 \\
0\end{array}$ & $\begin{array}{l}n \\
\hat{0} \\
0 \\
0\end{array}$ \\
\hline & $\underline{\widetilde{\nu}}$ & $\left|\begin{array}{l}9 \\
0 \\
0 \\
0\end{array}\right|$ & $\begin{array}{l}\stackrel{0}{0} \\
\stackrel{0}{0} \\
0\end{array}$ & $\stackrel{m}{m}$ & 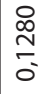 & 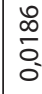 & $\begin{array}{l}\text { o } \\
0 \\
0 \\
0\end{array}$ & $\mid \begin{array}{l}n \\
0 \\
0 \\
0\end{array}$ & $\begin{array}{l}0 \\
\infty \\
0 \\
0\end{array}$ & $\mid \begin{array}{l}0 \\
\hat{0} \\
0 \\
0\end{array}$ & $\mid \begin{array}{l}0 \\
0 \\
0 \\
0\end{array}$ & $\begin{array}{l}\stackrel{+}{m} \\
\stackrel{m}{0} \\
0\end{array}$ & 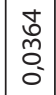 & $\begin{array}{l}\text { o } \\
0 \\
0 \\
0\end{array}$ & $\left|\begin{array}{l}\tilde{N} \\
\tilde{0} \\
0\end{array}\right|$ & $\mid \begin{array}{l}\pi \\
0 \\
0 \\
0 \\
0\end{array}$ & $\begin{array}{l}\tilde{o} \\
\frac{m}{0}\end{array}$ & $\begin{array}{l}0 \\
\hat{2} \\
0 \\
0\end{array}$ \\
\hline & $\bar{x}$ & $\left|\begin{array}{l}0 \\
\tilde{0} \\
0 \\
0\end{array}\right|$ & 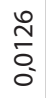 & $\frac{0}{\frac{0}{0}}$ & 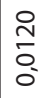 & 욤 & 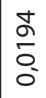 & $\mid \begin{array}{l}\tilde{o} \\
0 \\
0 \\
0\end{array}$ & $\begin{array}{l}\circ \\
\stackrel{0}{0} \\
0\end{array}$ & $\left|\begin{array}{l}\infty \\
0 \\
0 \\
0\end{array}\right|$ & $\left|\begin{array}{l}0 \\
\tilde{0} \\
0 \\
0\end{array}\right|$ & $\begin{array}{l}\text { f } \\
\text { ठn. } \\
\text {. }\end{array}$ & 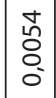 & $\begin{array}{l}\infty \\
\infty \\
0 \\
0 \\
0\end{array}$ & $\left|\begin{array}{l}n \\
\tilde{O} \\
0 \\
0\end{array}\right|$ & $\mid \begin{array}{l}\bar{n} \\
0 \\
0 \\
0\end{array}$ & $\mid \begin{array}{l}\hat{0} \\
\hat{0} \\
0 \\
0\end{array}$ & $\begin{array}{l}\text { Oे } \\
\stackrel{0}{0} \\
\text { - }\end{array}$ \\
\hline & $\sum^{m}$ & $\underset{\widetilde{N}}{\tilde{O}}$ & $\frac{\mathbb{N}}{\delta}$ & \& & ஜ্లి & $\begin{array}{l}0 \\
0 \\
0 \\
0\end{array}$ & $\begin{array}{l}\mathscr{0} \\
\text { on. }\end{array}$ & $\mid \begin{array}{l}n \\
\hat{0} \\
0 \\
0\end{array}$ & ঃ & \begin{tabular}{|l|}
0 \\
0 \\
0 \\
0
\end{tabular} & $\begin{array}{l}\tilde{z} \\
\text { oे } \\
0 \\
0\end{array}$ & $\begin{array}{l}\text { O̊n } \\
0\end{array}$ & $\begin{array}{l}0 \\
0 \\
0 \\
0\end{array}$ & $\begin{array}{l}\infty \\
\infty \\
o \\
0\end{array}$ & $\mid \begin{array}{l}\hat{\tilde{o}} \\
0 \\
0 \\
0\end{array}$ & 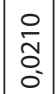 & $\mid \begin{array}{c}0 \\
0 \\
0 \\
0 \\
0\end{array}$ & $\begin{array}{l}\frac{0}{1} \\
\vdots \\
0\end{array}$ \\
\hline \multirow{3}{*}{ 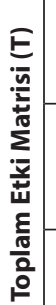 } & $\Sigma$ & $\mid$\begin{tabular}{c}
0 \\
\multirow{y}{y}{} \\
0 \\
0 \\
0
\end{tabular} & $\begin{array}{l}\overline{1} \\
\vdots \\
0 \\
0\end{array}$ & $\begin{array}{l}\hat{N} \\
\hat{O} \\
0 \\
0\end{array}$ & $\frac{\bar{\delta}}{0}$ & $\frac{\stackrel{\circ}{\circ}}{\circ}$ & $\frac{8}{0}$ & $\begin{array}{l}0 \\
0 \\
0 \\
0 \\
0\end{array}$ & 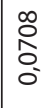 & 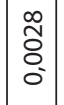 & $\begin{array}{l}\hat{\vartheta} \\
\vdots \\
0\end{array}$ & 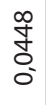 & $\begin{array}{l}0 \\
0 \\
\frac{0}{2} \\
\vdots\end{array}$ & $\mid \begin{array}{l}\infty \\
\prod_{\hat{O}} \\
0 \\
0\end{array}$ & 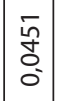 & $\mid \begin{array}{l}n \\
\hat{T} \\
0 \\
0 \\
0\end{array}$ & $\mid \begin{array}{l}0 \\
8 \\
o \\
0 \\
0\end{array}$ & 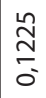 \\
\hline & $\Sigma$ & $\begin{array}{l}0 \\
0 \\
0 \\
0\end{array}$ & 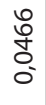 & g & 욤 & $\frac{a}{6} \frac{0}{0}$ & $\stackrel{\substack{n \\
\frac{1}{\sigma}}}{ }$ & $\begin{array}{l}\hat{\hat{n}} \\
\hat{0} \\
0 \\
0\end{array}$ & $\begin{array}{l}\frac{n}{\pi} \\
\stackrel{n}{0} \\
0\end{array}$ & $\mid \begin{array}{l}0 \\
\tilde{o} \\
0 \\
0 \\
0\end{array}$ & $\frac{\frac{J}{m}}{\frac{m}{0}}$ & $\begin{array}{l}\text { Оे } \\
\text { ò } \\
\text { - }\end{array}$ & $\begin{array}{l}n \\
\hat{n} \\
0 \\
0 \\
0\end{array}$ & $\frac{\frac{g}{f}}{\delta}$ & 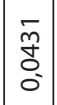 & $\mid \begin{array}{l}n \\
\frac{n}{\sigma} \\
\sigma \\
\end{array}$ & $\mid \begin{array}{c}N \\
\hat{n} \\
\tilde{o} \\
\end{array}$ & $\begin{array}{l}\stackrel{L}{0} \\
\frac{0}{0}\end{array}$ \\
\hline & & $\bar{\Sigma}$ & 2 & $z$ & - & $\underline{x}$ & $x$ & $F$ & $\vdash$ & $\stackrel{m}{*}$ & 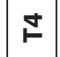 & $\bar{\omega}$ & జ & u & 壱 & $\overline{>}$ & $\underset{>}{>}$ & $>$ \\
\hline
\end{tabular}

\begin{tabular}{|c|c|c|c|c|c|}
\hline . & $\begin{array}{l}8 \\
\vdots \\
0 \\
0\end{array}$ & $\begin{array}{l}\frac{n}{0} \\
\frac{0}{0}\end{array}$ & 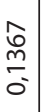 & $\begin{array}{l}\text { ¿ิ } \\
\frac{0}{0}\end{array}$ & $\begin{array}{l}\bar{o} \\
\vdots \\
0 \\
0\end{array}$ \\
\hline س & $\begin{array}{l}\hat{\widehat{o}} \\
0 \\
0\end{array}$ & $\begin{array}{c}\frac{7}{2} \\
\frac{n}{0} \\
\end{array}$ & 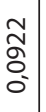 & $\begin{array}{l}0 \\
\stackrel{0}{0} \\
\vdots \\
0 \\
0\end{array}$ & $\frac{\text { f }}{\lesssim}$ \\
\hline$\vdash$ & $\begin{array}{l}9 \\
0 \\
0 \\
0\end{array}$ & $\begin{array}{l}\text { mo } \\
\text { ô } \\
0\end{array}$ & \begin{tabular}{l}
\multirow{N}{*}{} \\
0 \\
0 \\
0
\end{tabular} & $\begin{array}{c}\infty \\
\stackrel{\infty}{0} \\
\stackrel{m}{0} \\
0\end{array}$ & 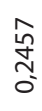 \\
\hline$\leq$ & $\begin{array}{l}\hat{\tilde{o}} \\
0 \\
0\end{array}$ & $\begin{array}{l}\stackrel{o}{0} \\
o \\
0 \\
0\end{array}$ & $\begin{array}{l}8 \\
\frac{0}{\circ} \\
\frac{0}{0}\end{array}$ & $\begin{array}{l}n \\
\stackrel{2}{\circ} \\
\vdots \\
\circ\end{array}$ & $\begin{array}{c}\hat{n} \\
\infty \\
m \\
0 \\
0\end{array}$ \\
\hline$\Sigma$ & $\begin{array}{l}\overline{2} \\
0 \\
0 \\
0\end{array}$ & 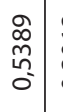 & $\begin{array}{c}\tilde{N} \\
\tilde{m} \\
\tilde{c}\end{array}$ & $\begin{array}{l}\sigma \\
\frac{\sigma}{t} \\
0\end{array}$ & $\begin{array}{l}\stackrel{+}{\infty} \\
\stackrel{+}{0} \\
0\end{array}$ \\
\hline & $\Sigma$ & 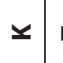 & $\vdash$ & $\boldsymbol{\omega}$ & $>$ \\
\hline
\end{tabular}




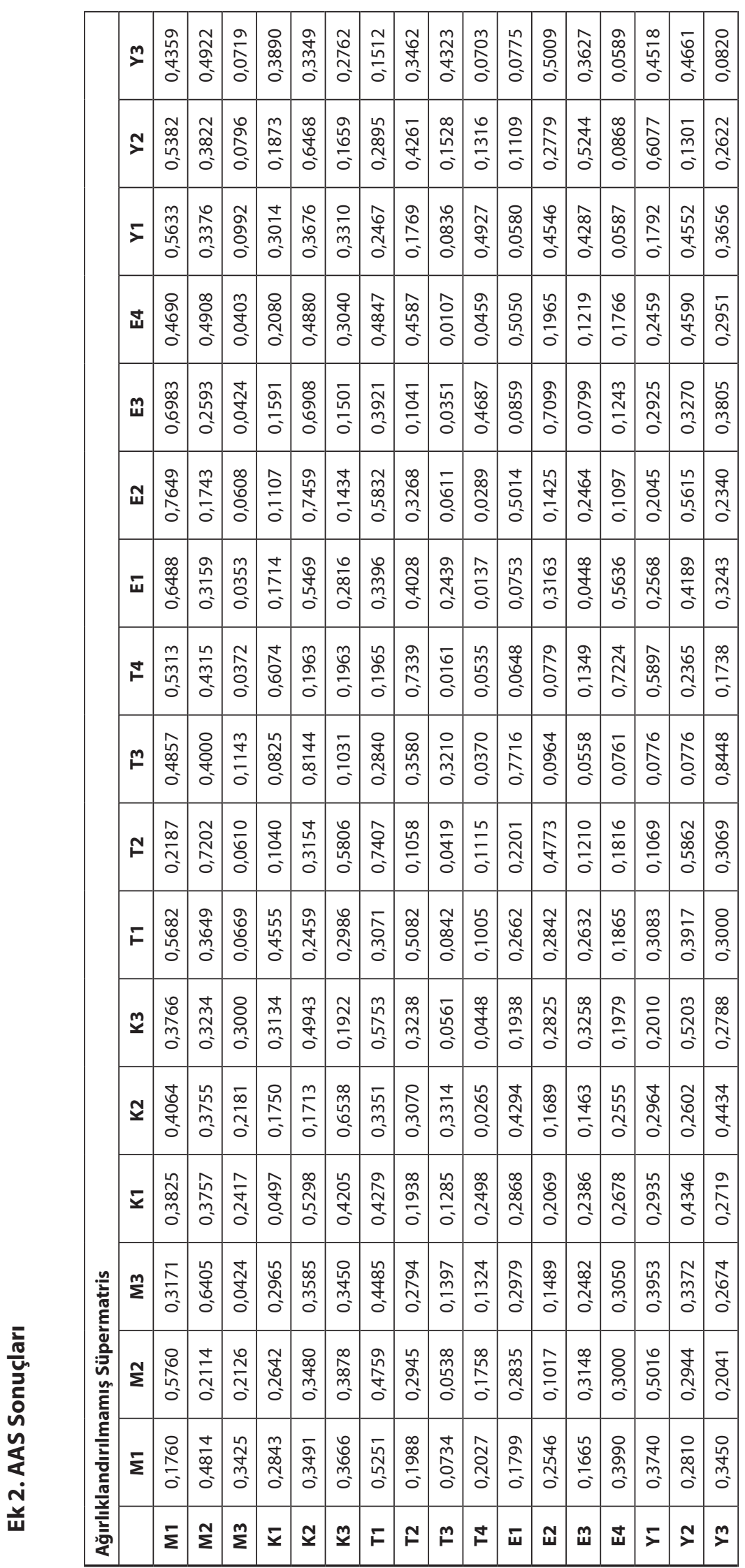




\begin{tabular}{|c|c|c|c|c|c|c|c|c|c|c|c|c|c|c|c|c|c|c|c|c|c|c|c|c|c|c|c|c|c|c|c|c|c|c|}
\hline & & $y$ & $\frac{\vdots}{b}$ & & 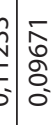 & & & & $\begin{array}{l}2 \\
\hat{\alpha} \\
0 \\
0\end{array}$ & & & $\left.\begin{array}{l}0 \\
0 \\
0 \\
\vdots \\
0\end{array}\right]$ & \begin{tabular}{l|l}
0 \\
0 \\
$\vdots$ \\
$\vdots$ \\
0 \\
0
\end{tabular} & ba & 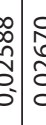 & 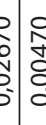 & & $m$ & & & & & & & & & 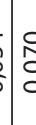 & & & \begin{tabular}{l}
\multirow{2}{t}{} \\
$\vdots$ \\
$\vdots$
\end{tabular} & & & & \\
\hline & & 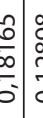 & 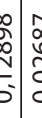 & & 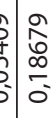 & $\mid \begin{array}{l}\alpha \\
\hat{\sigma} \\
\delta \\
0 \\
0\end{array}$ & $\mid \begin{array}{l}\hat{n} \\
\hat{0} \\
0\end{array}$ & {$\left[\begin{array}{l}\infty \\
0 \\
0 \\
0 \\
0\end{array}\right]$} & 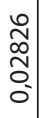 & 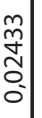 & & 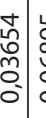 & 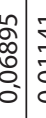 & 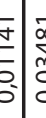 & 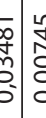 & 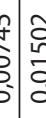 & & $\underset{\nearrow}{\searrow}$ & & 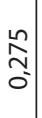 & $\begin{array}{l}\tilde{0} \\
0 \\
0\end{array}$ & $\begin{array}{c}0 \\
\vdots \\
0\end{array}$ & 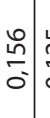 & $\stackrel{2}{\simeq}$ & & & & & $\left|\begin{array}{l}\hat{1} \\
0 \\
0\end{array}\right|$ & \begin{tabular}{l}
\multirow{2}{\Delta}{} \\
$\vdots$ \\
0 \\
0
\end{tabular} & $\begin{array}{l}8 \\
0 \\
0 \\
0\end{array}$ & & \begin{tabular}{lll}
0 & \multicolumn{2}{c}{} \\
& 8 \\
$O$
\end{tabular} & \\
\hline & & $\frac{8}{0}$ & $\begin{array}{c}n=0 \\
s \\
s\end{array}$ & s & 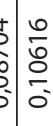 & $\begin{array}{l}0 \\
0 \\
0 \\
0 \\
0 \\
0\end{array}$ & $\mid$ & 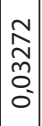 & 盀 & & 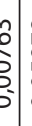 & o. & 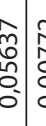 & s. & $\begin{array}{c}5 \\
5 \\
5 \\
\end{array}$ & 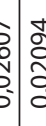 & & $\mp 1$ & m. & $\begin{array}{l}\stackrel{n}{\hat{N}} \\
0 \\
0\end{array}$ & $\begin{array}{l}\frac{2}{0} \\
0 \\
0\end{array}$ & $\begin{array}{l} \pm \\
\vdots \\
0\end{array}$ & 迥 & $\begin{array}{c}\stackrel{2}{2} \\
0 \\
\end{array}$ & & & & & $\begin{array}{l}\hat{0} \\
0 \\
0\end{array}$ & & & & & \\
\hline & & 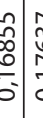 & $\begin{array}{l}n \\
0 \\
0 \\
0\end{array}$ & & 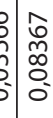 & 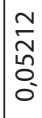 & $\left.\mid \begin{array}{c}0 \\
m \\
0 \\
0\end{array}\right]$ & $\mid \begin{array}{l}\frac{1}{n} \\
\underset{n}{0} \\
0 \\
0\end{array}$ & 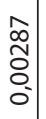 & & 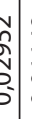 & 8 & 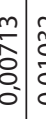 & 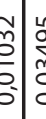 & 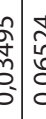 & 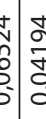 & & $\mathbf{f}$ & $n$ & 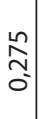 & $\begin{array}{l}\frac{1}{0} \\
0 \\
0\end{array}$ & $\begin{array}{l}0 \\
\stackrel{0}{0} \\
0\end{array}$ & $\begin{array}{l}0 \\
n \\
1\end{array}$ & $\stackrel{2}{\simeq}$ & & & 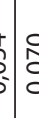 & & $\left|\begin{array}{l}\hat{1} \\
0 \\
0 \\
0\end{array}\right|$ & $\delta$ & & & $\begin{array}{c}0 \\
0 \\
\end{array}$ & \\
\hline & & 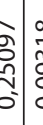 & 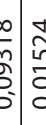 & & 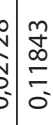 & $\mid \begin{array}{l}\hat{n} \\
0 \\
0 \\
0\end{array}$ & $\mid \begin{array}{l}\hat{n} \\
0 \\
0 \\
0\end{array}$ & & $\begin{array}{l}\mathfrak{z} \\
\text { s. } \\
\text { o. } \\
0\end{array}$ & & 8 & ○ & $\begin{array}{l}0 \\
\vdots \\
\vdots \\
0 \\
0 \\
0\end{array}$ & ț & 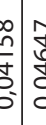 & 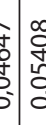 & & m & $\frac{\sigma}{m}$ & 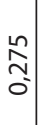 & $\begin{array}{l}\frac{2}{0} \\
\frac{0}{0}\end{array}$ & $\begin{array}{c}0 \\
0 \\
0\end{array}$ & $\begin{array}{c}0 \\
\\
\vdots\end{array}$ & $\begin{array}{l}\hat{\imath} \\
0 \\
0\end{array}$ & 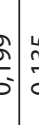 & 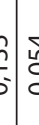 & & & $\mid \begin{array}{l}1 \\
0 \\
0 \\
0\end{array}$ & \pm & 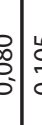 & & ? & \\
\hline & & ב. & 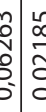 & 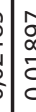 & 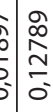 & 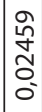 & $\mid \begin{array}{l}\mid \\
\\
0 \\
0\end{array}$ & $\mid \begin{array}{l}\hat{0} \\
0 \\
0 \\
0\end{array}$ & 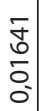 & & & 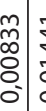 & 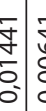 & 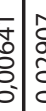 & 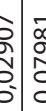 & 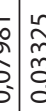 & & $\mathbf{w}$ & 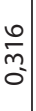 & 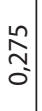 & $\begin{array}{l}\frac{0}{0} \\
0 \\
0\end{array}$ & $\begin{array}{l}\frac{5}{0} \\
\stackrel{0}{0} \\
\end{array}$ & $\begin{array}{l}0 \\
\\
0\end{array}$ & $\begin{array}{l}\stackrel{2}{0} \\
0 \\
0\end{array}$ & 7 & 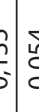 & & & $\begin{array}{l}1 \\
0 \\
0\end{array}$ & \begin{tabular}{l}
\multirow{2}{t}{} \\
$\vdots$ \\
$\vdots$ \\
0
\end{tabular} & & & $\frac{8}{\circ}$ & \\
\hline & & ç. & 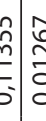 & & 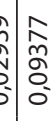 & 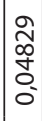 & 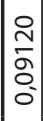 & $\left|\begin{array}{c|}0 \\
0 \\
0 \\
0 \\
0\end{array}\right|$ & \begin{tabular}{l}
0 \\
\multirow{2}{0}{} \\
0 \\
0 \\
0
\end{tabular} & 竎 & 8 & $\delta_{0}^{0}$ & 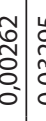 & 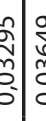 & 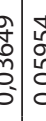 & 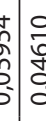 & & $\bar{\omega}$ & $\frac{0}{m}$ & 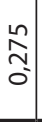 & $\begin{array}{l}\frac{1}{0} \\
\frac{0}{\sigma}\end{array}$ & $\begin{array}{l}\frac{1}{0} \\
\frac{0}{0}\end{array}$ & $\begin{array}{c}0 \\
\stackrel{n}{0} \\
\vdots\end{array}$ & \begin{tabular}{l}
$\stackrel{2}{0}$ \\
\hdashline \\
0
\end{tabular} & & . & & & $\mid \begin{array}{l}1 \\
0 \\
0 \\
0\end{array}$ & 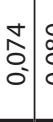 & & & & \\
\hline & & $\begin{array}{c}n \\
2 \\
\vdots \\
\vdots\end{array}$ & 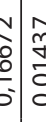 & & 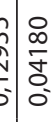 & $\begin{array}{l}\frac{0}{\infty} \\
\frac{\infty}{\delta} \\
0 \\
0\end{array}$ & $\begin{array}{c}0 \\
\vdots \\
0 \\
0 \\
0\end{array}$ & $\left|\begin{array}{l}\tilde{N} \\
0 \\
0 \\
0 \\
0\end{array}\right|$ & $\begin{array}{l}\frac{1}{2} \\
\bar{o} \\
0 \\
0\end{array}$ & $\begin{array}{l}m \\
\\
o \\
0 \\
0\end{array}$ & & $\begin{array}{c}\vdots \\
\delta\end{array}$ & 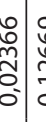 & 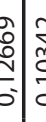 & $\begin{array}{ll}y \\
\frac{y}{b} \\
\frac{c}{b}\end{array}$ & 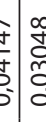 & & 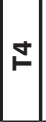 & $\stackrel{\circ}{m}$ & 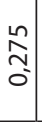 & $\begin{array}{l}\frac{1}{0} \\
\frac{0}{\delta}\end{array}$ & $\begin{array}{l} \pm \\
\vdots \\
\vdots\end{array}$ & 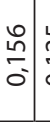 & $\begin{array}{l}\mathfrak{n} \\
\vdots \\
0\end{array}$ & ร & 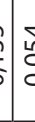 & & & $\begin{array}{l}\hat{1} \\
0 \\
0\end{array}$ & & & & & \\
\hline & & 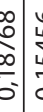 & 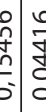 & 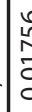 & 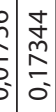 & 赑 & $\left|\begin{array}{l}m \\
0 \\
0 \\
0 \\
0\end{array}\right|$ & $\mid \begin{array}{l}\bar{m} \\
\infty \\
0 \\
0 \\
0\end{array}$ & 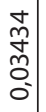 & 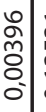 & & 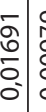 & 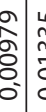 & 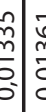 & 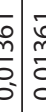 & 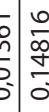 & & 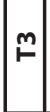 & $\frac{0}{m}$ & 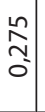 & $\frac{\tilde{\sigma}}{\sigma}$ & $\begin{array}{l}t \\
0 \\
0\end{array}$ & $\begin{array}{l}c \\
\\
0\end{array}$ & $\begin{array}{l}\stackrel{n}{\mathfrak{n}} \\
\vdots \\
\vdots\end{array}$ & f & ப & & & $\begin{array}{l}1 \\
0 \\
0 \\
0\end{array}$ & t) & & & & \\
\hline & & $\begin{array}{l}n \\
\vdots \\
0 \\
0 \\
0 \\
0\end{array}$ & 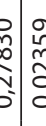 & & 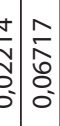 & $\mid \begin{array}{l}1 \\
\stackrel{0}{2} \\
\cong \\
0\end{array}$ & $\left|\begin{array}{l}2 \\
\alpha \\
\hat{0} \\
0 \\
0\end{array}\right|$ & $\left|\begin{array}{c}\tilde{m} \\
\hdashline \\
0 \\
0 \\
0\end{array}\right|$ & $\begin{array}{l}\frac{o}{q} \\
8 \\
0 \\
0\end{array}$ & $\begin{array}{l}0 \\
0 \\
\\
0 \\
0\end{array}$ & & 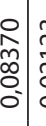 & 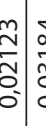 & 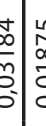 & 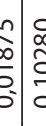 & 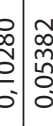 & & $\mathrm{N}$ & $\frac{m}{m}$ & $\left|\begin{array}{c}\stackrel{n}{\hat{N}} \\
\delta\end{array}\right|$ & $\begin{array}{l}\frac{2}{0} \\
\frac{0}{\circ}\end{array}$ & $\begin{array}{l}0 \\
0 \\
0\end{array}$ & $\begin{array}{l}0 \\
\stackrel{2}{0} \\
\vdots\end{array}$ & $\begin{array}{l}\tilde{\imath} \\
\stackrel{0}{0}\end{array}$ & & 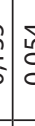 & & & $\mid \begin{array}{l}\hat{0} \\
0 \\
0\end{array}$ & \begin{tabular}{l|l}
$\dot{t}$ & \\
$\vdots$ & $\vdots$ \\
0 &
\end{tabular} & $\begin{array}{l}8 \\
0 \\
0 \\
0\end{array}$ & & & \\
\hline & $F$ & 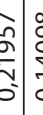 & 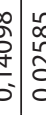 & & 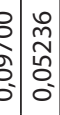 & $\begin{array}{l}\stackrel{0}{0} \\
0 \\
0 \\
0 \\
0\end{array}$ & $\mid \begin{array}{l}n \\
\infty \\
0 \\
0 \\
0 \\
0\end{array}$ & $\mid \begin{array}{l}\hat{y} \\
\hat{y} \\
\hat{d} \\
0 \\
0\end{array}$ & $\begin{array}{l}\bar{\sigma} \\
\bar{o} \\
0 \\
0\end{array}$ & $\begin{array}{l}0 \\
\vdots \\
0 \\
0 \\
0\end{array}$ & f & 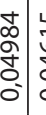 & 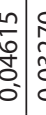 & $\begin{array}{lll}0 & \\
0 \\
c \\
0 \\
0\end{array}$ & 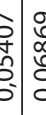 & 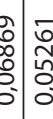 & & $F$ & 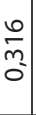 & 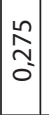 & $\frac{\widetilde{\partial}}{0}$ & $\begin{array}{l} \pm \\
\frac{0}{0} \\
\end{array}$ & $\begin{array}{c}0 \\
\stackrel{n}{0} \\
0\end{array}$ & $\begin{array}{l}\hat{n} \\
\vdots \\
0\end{array}$ & & 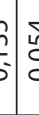 & 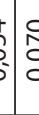 & & $\begin{array}{l}1 \\
0 \\
0\end{array}$ & $\begin{array}{l}t \\
\grave{0} \\
\vdots\end{array}$ & & & : & \\
\hline & & $\begin{array}{c}\bar{N} \\
\vdots \\
b\end{array}$ & $\frac{1}{5}$ & & $0_{0}^{0}$ & 蔍 & $\frac{5}{5}$ & 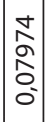 & 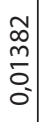 & $\begin{array}{l}\tilde{c} \\
0 \\
0 \\
0 \\
0\end{array}$ & & 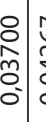 & 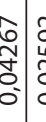 & 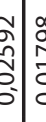 & 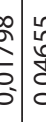 & 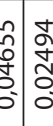 & & $\underline{\mathbf{m}}$ & $\frac{6}{m}$ & 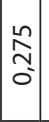 & $\begin{array}{l}0 \\
0 \\
0 \\
0\end{array}$ & 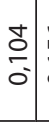 & \begin{tabular}{l}
0 \\
$\stackrel{2}{n}$ \\
\hdashline
\end{tabular} & $\begin{array}{l}\hat{n} \\
\vdots \\
-\end{array}$ & & 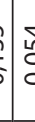 & 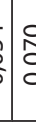 & & $\begin{array}{l}\hat{0} \\
0 \\
0\end{array}$ & 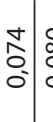 & & & & \\
\hline & $q$ & $\begin{array}{c}6 \\
0 \\
0 \\
0\end{array}$ & 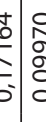 & & 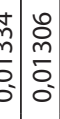 & $\begin{array}{l}2 \\
\infty \\
o \\
o \\
0 \\
0 \\
0\end{array}$ & $\mid \begin{array}{c}\bar{n} \\
0 \\
0 \\
0 \\
0\end{array}$ & $\left|\begin{array}{l}0 \\
0 \\
h \\
0 \\
0 \\
0\end{array}\right|$ & $\begin{array}{l}\stackrel{\circ}{\circ} \\
\stackrel{0}{0} \\
0 \\
0\end{array}$ & $\begin{array}{l}\text { స̂े } \\
\text { on } \\
0\end{array}$ & & 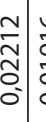 & 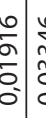 & 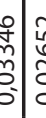 & 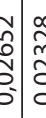 & 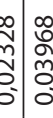 & & 1 & $\frac{o}{m}$ & $\left|\begin{array}{c}\tilde{n} \\
\hat{n} \\
0\end{array}\right|$ & $\begin{array}{l}\frac{s}{0} \\
\frac{0}{\circ}\end{array}$ & $\begin{array}{l}\ddagger \\
0 \\
0\end{array}$ & $\begin{array}{l}0 \\
\stackrel{2}{0} \\
0\end{array}$ & $\begin{array}{l}\stackrel{2}{n} \\
0 \\
0\end{array}$ & & 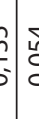 & & & $\mid \begin{array}{l}1 \\
0 \\
0\end{array}$ & & & & & \\
\hline & $\bar{\Sigma}$ & \begin{tabular}{ccc}
0 \\
\hdashline \\
\hdashline \\
\end{tabular} & $=$ & & 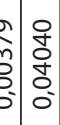 & $\mid \begin{array}{l}\hat{i} \\
\tilde{N} \\
0 \\
0 \\
0\end{array}$ & $\left.\mid \begin{array}{l}n \\
\tilde{n} \\
0 \\
0 \\
0\end{array}\right]$ & $\mid \begin{array}{c}m \\
\hat{f} \\
0 \\
0 \\
0\end{array}$ & 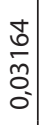 & $\begin{array}{l}\bar{n} \\
\bar{n} \\
8 \\
0 \\
0\end{array}$ & & $\begin{array}{c}\tilde{c} \\
0 \\
\delta\end{array}$ & 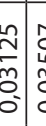 & 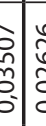 & 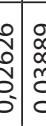 & 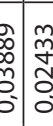 & & $\bar{\Sigma}$ & 6 & $\left|\begin{array}{l}n \\
\hat{n} \\
0\end{array}\right|$ & $\begin{array}{l}\frac{2}{0} \\
0 \\
0\end{array}$ & $\begin{array}{l}0 \\
0 \\
0\end{array}$ & \begin{tabular}{c}
0 \\
\\
\hdashline
\end{tabular} & 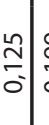 & & 5 & § & & $\begin{array}{l}1 \\
0 \\
0 \\
0\end{array}$ & & & & & \\
\hline & & 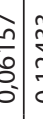 & $\begin{array}{c}n \\
n \\
b\end{array}$ & & 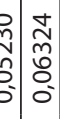 & $\begin{array}{l}\infty \\
0 \\
0 \\
0 \\
0\end{array}$ & $\left|\begin{array}{l}0 \\
0 \\
0 \\
\frac{0}{0} \\
\mid\end{array}\right|$ & $\mid \begin{array}{l}\mathbf{1} \\
\hat{N} \\
0 \\
0\end{array}$ & $\begin{array}{l}\hat{n} \\
0 \\
0 \\
0 \\
0\end{array}$ & 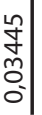 & & $\begin{array}{l}0 \\
0 \\
0 \\
0 \\
0 \\
0 \\
0\end{array}$ & 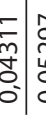 & 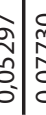 & 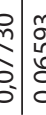 & 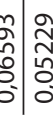 & & $\sum^{m}$ & $\frac{0}{m}$ & $\left|\begin{array}{l}n \\
\hat{N} \\
0\end{array}\right|$ & $\begin{array}{l}\frac{0}{0} \\
0 \\
0\end{array}$ & $\begin{array}{l} \pm \\
0 \\
0 \\
0\end{array}$ & $\begin{array}{c}0 \\
\stackrel{0}{n} \\
\vdots\end{array}$ & $\begin{array}{l}\stackrel{n}{\mathfrak{n}} \\
\vdots\end{array}$ & 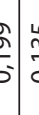 & 5 & § & & $\mid \begin{array}{l}1 \\
0 \\
0 \\
0\end{array}$ & 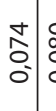 & & & & \\
\hline & $\Sigma$ & $\begin{array}{c}L_{0} \\
\\
\\
\end{array}$ & $\begin{array}{l}n \\
b \\
b \\
b\end{array}$ & & 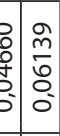 & \begin{tabular}{|l}
1 \\
0 \\
0 \\
0 \\
0 \\
0
\end{tabular} & 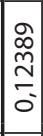 & $\begin{array}{l}1 \\
0 \\
0 \\
0 \\
0 \\
0\end{array}$ & $\begin{array}{l}\text { o. } \\
\hat{m} \\
\tilde{0} \\
0 \\
0\end{array}$ & $\begin{array}{l}\hat{1} \\
\vdots \\
\vdots \\
0 \\
0\end{array}$ & & 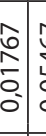 & \begin{tabular}{l|l}
0 \\
$\vdots$ \\
$\vdots$ \\
0 \\
0 \\
0
\end{tabular} & 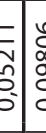 & 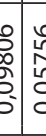 & 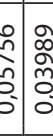 & & 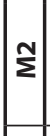 & & $\begin{array}{l}n \\
\hat{N} \\
\delta\end{array} \mid$ & $\begin{array}{l}\frac{2}{0} \\
\frac{0}{\sigma}\end{array}$ & $\begin{array}{l}\frac{t}{0} \\
0\end{array}$ & $\begin{array}{c}0 \\
\\
0\end{array}$ & $\begin{array}{l}\stackrel{n}{\mathfrak{o}} \\
\vdots\end{array}$ & & 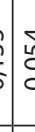 & & & $\begin{array}{l}1 \\
0 \\
0 \\
0\end{array}$ & 0 & & & $\frac{\infty}{0}$ & \\
\hline & & 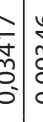 & 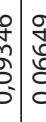 & & 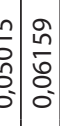 & : & $\left|\begin{array}{l}0 \\
0 \\
m \\
0 \\
0\end{array}\right|$ & $\mid \begin{array}{l}0 \\
0 \\
\hat{n} \\
0 \\
0\end{array}$ & $\begin{array}{l}0 \\
\vdots \\
\vdots \\
\vdots \\
0\end{array}$ & 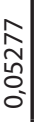 & & & 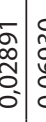 & $\begin{array}{lll}0 \\
0 \\
b \\
b \\
b\end{array}$ & 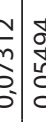 & 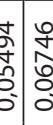 & & & & $\begin{array}{c}n \\
\hat{N} \\
0 \\
0\end{array}$ & $\begin{array}{l}\mathfrak{O} \\
0 \\
0\end{array}$ & 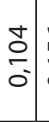 & $0^{\circ}$ & 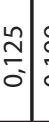 & & 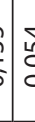 & 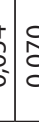 & & $\begin{array}{l}\hat{a} \\
0 \\
0\end{array}$ & 0 & $\begin{array}{l}8 \\
: \\
0 \\
0\end{array}$ & & & \\
\hline & & $\bar{\Sigma}$ & $\frac{N}{2} \mid \mathfrak{z}$ & & $\underline{\underline{x}}$ & ] & & $\mathfrak{F}$ & $\stackrel{m}{=}$ & $\vdash$ & & & $m$ & \pm 5 & $\Rightarrow>$ & & & & & $=1$ & $\sum_{\Sigma}^{m}$ & $\overline{\mathbf{z}}$ & $=$ & $m$ & & & & 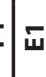 & ธิ & $\boldsymbol{m}$ & $\mathbb{H}$ & & & \\
\hline
\end{tabular}

